Specialist taxa restricted to threatened habitats contribute significantly to the regional diversity of Peltigera (Lecanoromycetes, Ascomycota) in Estonia

Juriado, Inga

2017-10-13

Juriado , I , Kaasalainen , U \& Rikkinen , J 2017 , ' Specialist taxa restricted to threatened habitats contribute significantly to the regional diversity of Peltigera (Lecanoromycetes, Ascomycota) in Estonia ' , Fungal Ecology , vol. 30 , pp. 76-87 . https://doi.org/10.1016/j.funeco.2017.08.004

http://hdl.handle.net/10138/298052

https://doi.org/10.1016/j.funeco.2017.08.004

cc_by_nc_nd

acceptedVersion

Downloaded from Helda, University of Helsinki institutional repository.

This is an electronic reprint of the original article.

This reprint may differ from the original in pagination and typographic detail.

Please cite the original version. 


\title{
Specialist taxa restricted to threatened habitats contribute significantly to the regional diversity of Peltigera (Lecanorales, Ascomycota) in Estonia
}

Inga Jüriado ${ }^{a, b}, *$, Ulla Kaasalainen ${ }^{c}$ and Jouko Rikkinen ${ }^{b, c}$

a Institute of Ecology and Earth Sciences, University of Tartu, Lai 38/40 Tartu 51005, Estonia.

${ }^{b}$ Department of Biosciences, University of Helsinki, P.O. Box 65, 00014, Helsinki, Finland.

${ }^{\mathrm{C}}$ Finnish Museum of Natural History, University of Helsinki, P.O. Box 7, Helsinki, Finland.

*Correspondence: Inga Jüriado; Institute of Ecology and Earth Sciences, University of Tartu, Lai 38/40 Tartu 51005, Estonia; E-mail: inga.juriado@ut.ee; telephone: + 3725168846

\begin{abstract}
The widespread cyanolichen genus Peltigera comprises many insufficiently known poorly delimited and/or undescribed species. Phylogenetic analysis of 252 Peltigera specimens from a wide range of habitat types in Estonia revealed 31 putative taxa (OTUs). Multivariate analysis revealed habitat-specific segregation between the Peltigera species along a gradient from humid eutrophic forests to dry oligotrophic forests and grasslands and along a soil $\mathrm{pH}$ gradient from alkaline soils of alvar grasslands to acidic soils of conifer forests. The diversity of Peltigera was the highest on roadsides and dunes and the lowest in alvar habitats which, however, supported the unique assemblage of undescribed Peltigera taxa. Deciduous broad-leaved forests, too, included several undescribed or rare and red-listed species. The results demonstrate that in Estonia many Peltigera species have narrow habitat requirements and are at present threatened by habitat loss and degradation.
\end{abstract}

Key words:

Diversity, cryptic species, habitat ecology, substrate specificity, dunes, roadsides, alvars, forests, parks

Introduction

Lichen symbioses are ecologically important in many terrestrial ecosystems. The cyanolichens, including Peltigera (Peltigeraceae, Lecanorales) species, play a particularly significant role as they can both photosynthesize and fix atmospheric nitrogen. Thus they are able to grow in nitrogen-limited environments and can also provide other organisms with fixed nitrogen (Hodkinson et al. 2014). Most Peltigera species are bipartite symbioses between the lichen-forming fungus (mycobiont) and one cyanobacterial photobiont (cyanobiont) which invariably belongs to the genus Nostoc. Some species represent more complex tripartite symbioses between the mycobiont and two photobionts, i.e. a photosynthetic green alga (Coccomyxa) and a nitrogen-fixing cyanobiont (Nostoc), respectively (Vitikainen 2007; Rikkinen 2015, 2017). 
Delimitation of morphological species in Peltigera is notoriously difficult (Holtan-Hartwig 1993; Vitikainen 1994, 2007; Goward et al. 1995). Although DNA studies have resolved some problems, in recent years, other problems still remain unresolved. Miadlikowska and Lutzoni (2000) showed that the genus includes eight well supported monophyletic linages (sections) that include a number of wellestablished morphological species and many more poorly delimited and undescribed taxa. A recent worldwide survey of the section Polydactylon identified many previously unrecognized putative species effectively doubling the number of known taxa in the section (Magain et al. 2017). These and concurrent findings indicate that biodiversity surveys that rely solely on phenotype characteristics can easily underestimate the true diversity of Peltigera species within a given region or environment ( $\mathrm{O}^{\prime} \mathrm{Brien}$ et al. 2009; Zúñiga et al. 2015).

Most Peltigera species are terricolous lichens growing on mineral soil, on peat, or among grounddwelling bryophytes. Many of them are pioneer lichens that thrive in early successional communities while others prefer mature forests where they typically grow on moss-covered soil and boulders, and on tree bases (Goward et al. 1995; Galloway 2000; Martínez et al. 2003; Vitikainen 2007; Smith et al. 2009). Some taxa in the latter group are quite specific about their requirements and susceptible to human induced changes in habitat quality. Therefore, a number of Peltigera species are categorized under threatened species in regional Red Lists (e.g. Liška et al. 2008; Randlane et al. 2008; Jääskeläinen et al. 2010; Marmor et al. 2017).

Recognition of cryptic fungal diversity is crucial for effective conservation of biological resources (Leavitt et al. 2013; Yahr et al. 2016). In Northern Europe habitat loss threatens not only pristine natural habitats (e.g. old-growth forests, dune environments) but also many semi-natural habitat types, including calcareous grasslands (Kuussaari et al. 2009; Cousins et al. 2015). For example, the gradual cessation of traditional land use practices in semi-natural alvar grasslands of NE Europe directly threatens many vascular plants, associated arthropods, and fungi (e.g. Eriksson et al. 2002; Öster 2008; Sang et al. 2010), as well as terricolous lichens (Leppik et al. 2013, 2015).

A number of epiphytic cyanolichens are known to be sensitive to environmental change (Ellis 2013; Rikkinen 2015). Their vulnerability to habitat loss and forest degeneration is well studied and documented (Goward and Arsenault 2000; Richardson and Cameron 2004). The diversity of epiphytic cyanolichens tends to correlate with tree species composition (Campbell et al. 2010; Aragón et al. 2013), as well as with stand age and continuity (Benson and Coxson 2002; Campbell and Freeden 2004). Because of their relatively poor dispersal ability, many cyanolichens are slow to colonize new habitats (Werth et al. 2006; Fedrowitz et al. 2012). While the influence of habitat quality on terricolous cyanolichens has not yet received much attention, some negative impacts of decreasing habitat quality on the diversity of terricolous cyanolichens have been reported (Ramírez-Fernández et al. 2013). The effect of habitat scale factors on cyanolichen communities is typically intermingled with impact of largescale processes such as air pollution and climate change (Ellis and Coppins 2007; Geiser and Neitlich 2007; Ellis 2012). In their recent analysis of the Mediterranean region, Rubio-Salcedo et al. (2016) found that cyanobacterial macrolichens are especially vulnerable to climate change. 
In this study we focus on the diversity of Peltigera in natural and semi-natural habitats in Estonia. The habitats include different grassland and forest types and collectively represent a natural gradient of decreasing atmospheric humidity, increasing soil pH, and increasing disturbance from acidic forest soils to basic alvar soils. We hypothesize that different Peltigera taxa are not randomly distributed along this complex environmental gradient, but that their species-specific distribution correlates with specific growth conditions and habitat types.

\section{Material and Methods}

Study region

Estonia is located in NE Europe on the eastern coast of the Baltic Sea, in the hemi-boreal sub-zone of the boreal forest zone. The region has a mild maritime climate with a mean annual temperature of 6.2 ${ }^{\circ} \mathrm{C}$ and precipitation of $600 \mathrm{~mm}$ (http://www.emhi.ee). The bedrock in Northern, Western and Central Estonia consists mainly of Ordovician and Silurian carbonate limestones, marls and dolomites, while Southern Estonia has Devonian sandstones and locally carbonate rocks, often covered by thick till layers (Raukas 1995). Sand dunes occur sporadically both near the coast and further inland (fossil dunes). Alvars are typical of the Baltic islands and occur also near the mainland's coastline. They are calcareous grasslands restricted to shallow skeletal soil (thickness less than $20 \mathrm{~cm}$ ) on Ordovician or Silurian calcareous sediments or on monolithic calcareous rock. Alvars have a rather limited overall distribution; in Northern Europe they only occur on the coasts and islands of the Baltic Sea (Rosén 1982; Pärtel et al. 2007; Johansson and Petersson 2016).

Study sites and sampling

In 2012-2016, a total of 271 specimens of Peltigera were collected from 75 study sites. The study sites were distributed all over Estonia and included three different wooded habitat types (oligotrophic forests, eutrophic forests, and park stands) and three different grassland types (alvars, dunes, and roadsides). The oligotrophic forests represented Cladina and Vaccinium vitis-idaea boreal forest site types dominated by Scots pine (Pinus sylvestris) on nutrient-poor soils. The eutrophic forests represented eutrophic and mesotrophic forest types, including herb-rich mixed forest on fertile soil, dominated either by temperate broad-leaved tree species (Aegopodium and Hepatica boreo-nemoral forest site types) or Norway spruce (Vaccinium myrtillus and Oxalis boreal forest site types). The park stands occurred in rural churchyards, cemeteries, or manor parks, dominated by broad-leaved trees and their stand structure was generally comparable to that of broad-leaved deciduous forests (Liira et al. 2012). The alvar grasslands mostly represented plate and ryhk alvars (Leppik et al. 2013, 2015; Jüriado et al. 2015). The dune grasslands were located along the seashore in Western Estonia and along the shores of Lake Peipsi in the northeast. The pioneer grasslands and the herb-rich grasslands prevailed on grey dunes (called 'grey' partly because of their dense lichen cover); communities of Calluna vulgaris and Empetrum nigrum were found on dune heaths (Jüriado et al. 2016). The roadside grasslands were mesic and xeric grasslands in the immediate vicinity of paved or unpaved roads. 
At each study site, up to three specimens of each morphologically distinguishable Peltigera taxon were collected for DNA analysis. Three substrate types were distinguished: ground, tree trunks, and rock. To further broaden the geographical cover of sampling, 32 Peltigera specimens from the herbarium of the Natural History Museum at the University of Tartu (TU) were included in the dataset (Table S1). To determine soil $\mathrm{pH}(\mathrm{KCl})$, organic matter and nutrient content $(\mathrm{Ca}, \mathrm{Mg}, \mathrm{K}, \mathrm{P}, \mathrm{N})$, soil samples, representing all studied habitat types except for the mesotrophic forests, were taken from 35 collection sites. These samples were analysed at the Laboratory of Plant Biochemistry of the Estonian University of Life Sciences. Prior to analysis, the samples were dried at $50^{\circ} \mathrm{C}$, ground and sieved, using a $2 \mathrm{~mm}$ sieve. The $\mathrm{pH}$ was determined in a suspension of $10 \mathrm{~g}$ of soil and $25 \mathrm{ml}$ of $1 \mathrm{~N} \mathrm{KCl}$. Total soil $\mathrm{N}$ was determined after Kjeldahl (Tecator ASN 3313 AOAC 2001.11, Page et al. 1982). Determination of available P in soil was done using Flow Injection Analysis (Page et al. 1982). Available K was determined from the same solution (ammonium lactate solution) by the Flame Photometric Method (956.01, KLK 1965). Exchangeable $\mathrm{Mg}$ was determined by Flow Injection Analysis (Page et al. 1982). Exchangeable Ca was determined from the same solution ( $1 \mathrm{M}$ ammonium acetate solution, $\mathrm{pH}=7.0$ ) by the Flame Photometric Method. Soil organic matter (loss on ignition) was determined after Schulte (1995).

Molecular data

Healthy Peltigera thalli without any visible symptoms of fungal infection were selected for molecular analysis. For DNA extraction, small thallus fragments from the terminal parts of lobes were taken under a dissecting microscope. The DNA was extracted using the GeneJET Genomic DNA Purification Kit (Thermo Scientific) following the manufacturer's protocol for Gram-Negative Bacteria. Amplification of the Internal Transcribed Spacer (ITS) region was done with the primer pair ITS 5F and ITS 4R (White et al. 1990) in a $50-\mathrm{ml}$ volume containing $4 \mu$ l genomic DNA, $37 \mu \mathrm{l}$ of sterile distilled water, $5 \mu \mathrm{l}$ of $10 \times$ buffer, $1 \mu \mathrm{l}$ dNTP (10 mM), $0.5 \mu \mathrm{l}$ ITS4, $0.5 \mu \mathrm{l}$ ITS5, $1.25 \mu \mathrm{l}$ BSA (20 mg/ml) (Thermo Scientific), $0.75 \mu \mathrm{l}$ Dynazyme II $(2 \mathrm{U} / \mu \mathrm{l})$ (Thermo Scientific). The heating cycle was the following: initial denaturation of 2 min at $94{ }^{\circ} \mathrm{C}$ was followed by 35 cycles of $30 \mathrm{sec}$ at $94{ }^{\circ} \mathrm{C}, 30 \mathrm{sec}$ at $57{ }^{\circ} \mathrm{C}$, and $30 \mathrm{sec}$ at $72{ }^{\circ} \mathrm{C}$, with a final extension of $10 \mathrm{~min}$ at $72{ }^{\circ} \mathrm{C}$. The amplification products were purified with the GeneJET PCR Purification Kit (Thermo Scientific). Sequencing was performed by Macrogen Inc. in Europe. The chromatograms of all sequences were checked, manually edited, and assembled using the program BioEdit 7.0.9 (Hall 1999) and CodonCode Aligner 6.0.2 (CodonCode Corporation, Dedham, MA, USA). All newly obtained sequences are deposited in the NCBI GenBank database (LT852805-LT853056) (Table S1). The voucher specimens are deposited in the lichenological herbarium of the Natural History Museum at the University of Tartu (TU).

Mycobiont ITS alignments and phylogenetic analyses

On the basis of Blast searches in the NCBI GenBank (http://blast.ncbi.nlm.nih.gov/Blast.cgi), each ITS sequence obtained from the Peltigera specimens analysed was classified under one of the five groups corresponding to the Peltigera sections Chloropeltigera, Horizontales, Peltidea, Peltigera, and Polydactylon, respectively (Miadlikowska and Lutzoni 2000). Alignments were performed separately for 
each group. Additionally, the sequences downloaded from the NCBI GenBank were included in the alignments to encompass the full known diversity of the studied groups.

The preliminary alignments of the fungal ITS sequences were performed using MAFFT (Katoh and Standley 2013). The reliability of the alignments was checked using the GUIDANCE server (Penn et al. 2010) and the alignments were corrected manually in PhyDE$^{\circledR} 1.0$ (Müller et al. 2005). Because of the very high sequence variation within the Peltigera section Peltigera, preliminary analyses were performed using the more conserved parts of the ITS region only. Based on these and previous results (Miadlikowska and Lutzoni 2000; Miadlikowska et al. 2003), the section Peltigera was further divided into two well supported phylogenetic groups: the Peltigera canina group, including the nominal species, and $P$. praetextata, $P$. membranacea, $P$. degenii, the putative species $P$. "neocanina" (Miadlikowska et al. 2003), and closely related taxa; and the Peltigera rufescens group, including the nominal species, $P$. didactyla, $P$. ponojensis, and closely related taxa. For further analyses, these two groups were aligned separately. Before final analyses, the unalignable part of the ITS1 region was removed and the length of the long single nucleotide repeat region was standardized within each taxon to remove possible variation caused by sequencing defaults. Alignment information (number of variable sites; Table S2) was calculated using DnaSP v5 (Librado and Rozas 2009).

The outgroups for the final analyses were selected on the basis of previous studies (Miadlikowska and Lutzoni 2000; Miadlikowska et al. 2003; Kaasalainen et al. 2013; Magain et al. 2017). The Bayesian analyses were performed with MrBayes 3.2.6 (Huelsenbeck and Ronquist 2001) on CIPRES Science Gateway (Miller et al. 2010). The dataset was divided into subsets corresponding to the regions ITS1, 5.8S, and ITS2. The best fitting nucleotide substitution model for each region was selected by means of the jModelTest using the Akaike and Bayesian information criteria (Posada 2008), and the General Time Reversible nucleotide substitution model with Gamma distributed rate variation among the sites and the proportion of Invariable sites $(G T R+\Gamma+I)$ was applied for all regions. The posterior probability distributions of the trees were calculated using the Metropolis-coupled Markov chain Monte Carlo (MCMCMC) method and the search strategies suggested by Huelsenbeck et al. $(2001,2002)$. Four runs with four chains $\left(1.5 \times 10^{7}\right.$ generations each) were set off simultaneously, with default settings. The chains were sampled for every 1,000 generations and the calculations of the consensus tree and of the posterior probability of the clades were performed based upon trees with a cut-off of $25 \%$. The convergence of the chains was confirmed with Tracer 1.5 (Rambaut and Drummond 2009). The trees were visualized, using TreeGraph 2.8.0 (Stöver and Müller 2010), and edited manually (Figures 1-3 and Supplementary material figures S1-S3). The nomenclature of Peltigera follows Vitikainen (2007).

Analyses of the ecological data

Direct ordination methods were used to assess the significance of the associations between lichen taxa and environmental variables. Canonical correspondence analysis (CCA) implemented in the program package CANOCO 5.0 (Šmilauer and Lepš 2014) was applied to evaluate the descriptive power of the environmental variables for species composition. The interactive forward selection procedure with 
randomization tests (Monte-Carlo permutation test) was employed to select the most important environmental variables influencing species composition.

To test the explanatory value of the habitat and substrate types, a dataset with 31 taxa from 107 study sites was compiled. Each specimen was assigned habitat type (alvar grassland, dune, roadside, eutrophic forest, oligotrophic forest, and park stands) and substratum type (tree, rock, ground) variables. In analyses, the substratum and habitat variables were combined ('ground_alvar', 'ground_dune', 'ground_eutrophic forest', 'tree_eutrophic forest', 'rock_roadside', 'rock_eutrophic forest' etc.). Rare taxa (with only 1-2 occurrences) and redundant specimens (several specimens of the same mycobiont ITS genotype from the same site) were excluded from ordination analyses. After exclusion, the final data matrix included 238 Peltigera specimens. Differences in species composition between the different habitats and substratum types were tested using the Multi-Response Permutation Procedures (MRPP) with the Euclidean distance, implemented in the program PC-ORD 6.15 (McCune and Mefford 2011). The Shannon Index (H) (Spellerberg and Fedor 2003) of diversity of Peltigera taxa in each habitat type was calculated using the same program. The Shannon index takes into account both the number of specimens and the number of taxa and varies from 0 for communities with a single taxon to high values for communities with numerous taxa, each with a few individuals.

To test the explanatory value of soil properties, a smaller dataset was compiled including 12 terricolous Peltigera taxa from 35 study sites, with 67 Peltigera specimens. The sites represented five different habitat types (4 oligotrophic forests, 4 parks, 11 dunes, 7 roadsides, and 9 alvar grasslands). The soil properties used as the explanatory variables were $\mathrm{pH}$, organic matter content, and soil $\mathrm{Ca}, \mathrm{Mg}, \mathrm{K}, \mathrm{N}$, and $\mathrm{P}$ content. With the exception of soil $\mathrm{pH}$, all variables were log transformed prior to analysis in order to reduce the effect of outlying values. The Kruskal-Wallis tests implemented in the program Statistica (StatSoft Inc.) were used to determine the statistical significance of the observed differences in soil chemistry between the different habitats.

Results

Phylogenetic delimitation of the lichen taxa

The phylogenetic analyses of the 252 fungal ITS sequences obtained from the Peltigera specimens grouped them into 31 OTUs (operational taxonomic units) (Table 1). The specimens represented five different sections of the genus Peltigera corresponding to the sections Chloropeltigera, Horizontales, Peltidea, Peltigera, and Polydactylon, respectively (Miadlikowksa and Lutzoni 2000). Most specimens (200) belonged to the Peltigera section Peltigera (Figs 1-3), comprising nine widely recognized or 'classical' Peltigera species ( $P$. degenii, $P$. membranacea, $P$. praetextata, $P$. canina, $P$. extenuata, $P$. didactyla, $P$. ponojensis, $P$. lepidophora, and $P$. rufescens), one recently described species (Peltigera islandica; Manoharan-Basil et al. 2016), three putative species ( $P$. "fuscoponojensis", P. "neocanina", and $P$. "neorufescens"), first identified by Miadlikowska et al. (2003), and several new putative species. The single specimen of $P$. islandica among the collected material shared an identical ITS sequence with previously analysed $P$. islandica specimens from other regions (Fig. 1). The putative new species included P. aff. "neocanina" (Fig. 1), and two or three species closely related to P. "neorufescens" and 
P. "fuscoponojensis" (in the P. "neorufescens" aggregate; Fig. 3). The Estonian specimens of $P$. canina s. lat. (Fig. 1) are divided into three groups, including monophyletic P. canina I and $P$. canina III (corresponding to $P$. canina s. lat. and $P$. canina s. str. in Manoharan-Basil et al. 2016), and paraphyletic $P$. canina II. Furthermore, $P$. didactyla includes three and $P$. ponojensis includes two phylogenetically distinct and well supported clades.

Altogether 21 of the Estonian specimens grouped into the Peltigera section Polydactylon and represented three different taxa: P. polydactylon (subsp. polydactylon; Magain et al. 2016), P. neopolydactyla, and $P$. hymenina (Fig. S1). The section Peltidea was represented by 14 Estonian

specimens, including $P$. aphthosa and $P$. malacea (Fig. S2A); the section Horizontales, by 11 specimens and two species, $P$. collina and $P$. neckeri (Fig. S3); and the section Chloropeltigera, by six specimens of P. leucophlebia fell into two clades, P. leucophlebia I (O'Brien et al. 2009) and P. leucophlebia IV (Fig. $\mathrm{S} 2 \mathrm{~B})$.

Habitat and substrate preferences

Most Peltigera specimens (73\%) were collected from the ground. Some specimens were collected from tree bases or logs (17\%) and mossy rocks (10 \%) (Table 2). All Peltigera specimens from alvars and dunes grew on soil; in all other habitats, specimens were also collected from mossy rocks (Table 2 ). In eutrophic forests specimens were largely collected from mossy tree bases and logs, most frequently those of Populus tremula, Quercus robur, Fraxinus excelsior, or Salix caprea. The number of Peltigera taxa was the highest in eutrophic forests and the lowest in oligotrophic forests and alvars (Table 2). The Shannon diversity index was the highest for roadside grasslands, parks and dunes, and the lowest for alvars (Table 2).

The CCA ordination of the Peltigera taxa and the combined variables of the substrate and habitat reveals differences in the habitat preferences of the different Peltigera taxa (Figs 4-5). The eigenvalues of the first three ordination axes are $0.63,0.51$, and 0.28 , respectively, and the explanatory variables explained $18 \%$ of total variance in the large species dataset. Forward selection of the explanatory variables showed that the variables 'ground_alvar' and 'tree_eutr.forest' made the largest contribution to the ordination result and explained the main division of the taxa in ordination analyses. Peltigera leucophlebia, P. "neorufescens" and P. "neorufescens" agg. III exhibited pronounced preference for the ground in alvar habitats (Fig. 4). Peltigera polydactylon and $P$. praetextata preferred tree bases and logs in eutrophic forests (Fig. 4). Also Peltigera aff. "neocanina", P. membranacea, and P. degenii preferred forest habitats whereas Peltigera aff. "neocanina" grew mainly on tree bases and $P$. membranacea and P. degenii preferred the ground and mossy stones and boulders (Fig. 4). Peltigera canina II, P. canina III, P. didactyla II and P. hymenina grew both on tree bases in sheltered woody habitats and in open dune grasslands (Fig. 4). The remaining taxa grew on the ground in xeric woodlands (park stands, oligotrophic forests), dunes or roadsides. Differences in the habitat preferences of these taxa are visualized along the third ordination axis (Fig. 5). Peltigera aphthosa, $P$. malacea and $P$. extenuata grew frequently on the soil in oligotrophic forests, whereas $P$. rufescens, $P$. neckerii and the putative species $P$. "fuscoponojens" were found on the ground in various habitats, most frequently on sand dunes (Fig. 5). 
Peltigera ponojensis I \& II, P. canina I and $P$. didactyla I were the most common in roadside grasslands and the putative species $P$. "neorufescens" agg. II preferred the soil in park stands (Fig. 5).

The MRPP tests confirmed that differences in the composition of the Peltigera species between the different habitats $(A=0.048, P<0.0001)$ and substratum types $(A=0.027, P<0.0001)$ were highly significant. In pairwise comparisons, significant differences in species composition were detected between alvars and all other habitat types $(P<0.01$ and $P<0.0001)$, and between eutrophic forests and all other habitats $(P<0.01$ and $P<0.0001)$, except for park stands $(p=0.26)$. Differences in species composition were significant also between 'trees' and the other two substratum types $(P<0.01)$ but not between 'ground' and 'rock' ( $p=0.123)$.

In the second CCA ordination analysis, the soil property variables explained $42.4 \%$ of total variance in the smaller species dataset. The eigenvalues of the first two ordination axes are 0.65 and 0.41 , respectively (Fig. 6). Assessment of the effects of each environmental variable demonstrated that all soil parameters, except for $\mathrm{P}$ content, contributed significantly to the CCA model $(p<0.05)$. However, among the habitat variables, only 'alvar' was significant $(p<0.05)$ in explaining the habitat preferences of the terricolous Peltigera taxa. Peltigera "neorufescens"agg. III and P. "neorufescens" were predominantly found on alvar soils with high $\mathrm{N}$ content. The lichen taxa favouring eutrophic soils, i.e. P. ponojensis I, P. canina I, and P. fuscoponojensis, grew frequently in roadside grasslands. Also $P$. ponojensis II and $P$. canina II preferred eutrophic soils while $P$. extenuata, $P$. canina III, and $P$. didactyla I grew frequently on acidic nutrient-poor soils (Fig. 6). The Kruskal-Wallis tests confirmed the statistical significance of the observed differences in soil chemistry between the different habitats. The most acidic soils were found in oligotrophic forests where soil $\mathrm{pH}$ was significantly lower than in alvar grasslands $(\mathrm{H}(4, \mathrm{~N}=35)=11.293, \mathrm{p}=0.0023)$ (Fig. S4A). The soils of alvar grasslands had significantly higher $\mathrm{N}, \mathrm{K}, \mathrm{Mg}$, Ca content, and contained more organic matter than the soils of dunes and oligotrophic forests (Fig. S4B-F). The soils of park stands and roadside grasslands had high $\mathrm{P}$ content and differed significantly from the soils of dunes in this respect ( $H=18.365, p=0.001)$ (Fig. S4G).

\section{Discussion}

Global biodiversity remains poorly known and most species remain undescribed (Costello et al. 2012, 2013; Pimm and Raven 2017). Among the lichen-forming fungi, many undescribed taxa are known to inhabit poorly studied regions and habitats, especially in tropical forests, and within overlooked taxonomic groups (Lumbsch et al. 2011; Hawksworth 2012; Yahr et al. 2016). Some of the monophyletic groups of Peltigera identified in this study show distinct ecological preferences and pending further morphological and chemical analyses, most of them probably represent new, previously unrecognized species. The high resolution of clades in the phylogenetic trees (Figs 1-3, S1-S3) and the accordance of our results with those of other studies, using multiple markers (e.g. Goffinet et al. 2003; Miadlikowska et al. 2003; Magain et al. 2016), support the opinion that in most cases the ITS region alone provides sufficient genetic information for distinguishing species within the genus Peltigera (Goffinet and Miadlikowska 1999; Lendemer and O'Brien 2011; Miadlikowska et al. 2014; Han et al. 2015). Our results exemplify also significant hidden diversity within relatively well known lichen groups and in 
comparatively well studied areas. Similar observations have recently been made in several other molecular studies (e.g. Lumbsch and Leavitt 2011; Divakar et al. 2016; Magain et al. 2017).

Species delimitation and habitat preferences

The studied dataset of the Estonian Peltigera specimens was comprehensive, representing five different sections of Peltigera (Miadlikowksa and Lutzoni 2000), of which the largest and the most diverse was the section Peltigera. Miadlikowska et al. (2003) identified two major monophyletic lineages within the section: the cinnamomea - canina - degenii group (CICADE) and the ponojensis - rufescens - didactyla group (PORUDI). Both groups were also found and supported by our phylogenetic analyses. The species of the CICADE-group are common in woodlands (mesophytic and subhygrophytic) and occur only rarely at xeric sites; the taxa of the PORUDI-group are xerophytic or at least to a far lesser degree mesophytic (Goward et al. 1995; Miadlikowska et al. 2003).

In the studied region the CICADE-group included four well established species (Peltigera degenii, $P$. membranacea, $P$. praetextata, $P$. canina), one relatively newly described species $(P$. islandica) which has previously only been reported from Iceland and Canada (Manoharan-Basil et al. 2016), the putative species P. "neocanina" (Miadlikowska et al. 2003; O'Brien et al. 2009), and a closely related possibly new taxon ( $P$. aff. "neocanina"; Fig. 1) which, apart from Estonia, has so far only been reported from Finland (Kaasalainen et al. 2013). Peltigera aff. "neocanina" seems to be mesophytic (Fig. 4) as its specimens were mostly collected from tree bases and mossy rocks in overgrown wooded meadows or eutrophic forests. Peltigera "neocanina" was only found on two occasions on mossy forest soils.

Phylogenetic analysis divided Peltigera canina into several groups, of which two were strongly supported (P. canina I and III in Fig. 1). According to Manoharan-Basil et al. (2016), clade III represents $P$. canina s. str. while at least clade I represents an additional distinct taxon. We found a clear difference in habitat ecology between these two clades. All specimens of $P$. canina clade I were collected from the ground mostly in relatively xeric habitats such as roadside grasslands and park stands (Figs 4-5). Conversely, the specimens of $P$. canina clade III were collected either from the ground at highly xeric sites, or from tree bases and rocks in eutrophic forests (Fig. 4). Similar habitat preferences were exhibited by the specimens of $P$. canina clade II. Further studies are required to determine whether the taxa in these lineages differ also in some aspects of thallus morphology and worldwide distribution patterns.

Anstett et al. (2013) found evidence that certain genotypes of $P$. praetextata were associated with particular substrates such as limestone or wood. In our study, all specimens represented the same genotype and were mostly collected from mossy tree bases in eutrophic forests (Fig. 1).

The PORUDI-group included Peltigera extenuata, $P$. didactyla, P. ponojensis, P. lepidophora, P. rufescens and several well supported additional putative taxa (Fig. 2). Peltigera extenuata typically grew on a sandy soil on dunes and in oligotrophic pine forests, in conditions that were more xeric than those reported by Goffinet and Hastings (1995). The specimens of $P$. didactyla fell into three phylogenetically distinctive clades with strong support. Peltigera didactyla clade I (Fig. 2) corresponds to Peltigera sp. 2 in a study of Goffinet et al. (2003, Figs 3-4). In our study Peltigera didactyla clade III corresponds to 
Peltigera sp. 3 and clade II represents $P$. didactyla s. str. There are some differences in the habitat ecology of these three clades. The specimens of $P$. didactyla clades I and III were collected from xeric habitats, mostly dunes, while some specimens of clade II grew at humid sites like mossy tree bases in eutrophic forests.

The specimens of Peltigera ponojensis grouped into two well supported sister clades, without any clear differences in the habitat preferences between these groups. Most specimens were collected from roadsides and dunes, generally on a eutrophic calcareous soil; in some cases the two genotypes were found in the same locality. Peltigera lepidophora is well known to prefer calcareous and/or nutrientrich substrates (Vitikainen 2007) and it also occurs in alvars (Leppik et al. 2013).

The Estonian Peltigera rufescens group included $P$. rufescens s. str., the two tentative species $P$. "fuscoponojensis" and P. "neorufescens" (Miadlikowska and Luzoni 2000; Miadlikowska et al. 2003), and three previously unreported, well supported clades forming the $P$. "neorufescens" aggregate in Fig. 3. The specimens of $P$. rufescens s. str. were collected from xeric habitats, frequently on acidic soils. The putative species $P$. "fuscoponojensis" was typically found in xeric grasslands with high soil pH (Fig. 6). Peltigera "neorufescens" was found at no less than 12 sites, again from xeric calcareous grasslands with high soil $\mathrm{pH}$.

The new clades of $P$. "neorufescens" agg. have so far only been reported from Estonia. The specimens of clade I and II were collected from several habitat types, whereas the specimens of clade III were restricted to alvar grasslands (Figs 4,6). Clear differences in ecological preferences between the clades suggests that there are at least two undescribed taxa in the group.

Peltigera polydactylon from the section Polydactylon was found exclusively in deciduous eutrophic and mixed mesotrophic forests, where it usually grew on tree bases and mossy logs. Peltigera neopolydactyla and $P$. hymenina were found only infrequently; both are known to favour humid forest environments (Vitikainen 1994, 2007). Traditionally, P. neopolydactyla was thought to have an almost worldwide distribution (Holtan-Hartwig 1993; Vitikainen 1994, 2007; Goward et al. 1995); however, this species concept has since been shown to be polyphyletic (Magain et al. 2017).

Peltigera leucophlebia, the sole species of the section Chloropeltidea in Estonia, was found on several occasions in dry alvar grasslands. Previous studies have shown that $P$. leucophlebia too consists of several cryptic species with some morphological differences (O'Brien et al. 2009); our phylogenetic analysis also confirmed the existence of several distinct clades (Fig. S2B). Interestingly, one of them (clade IV) includes Estonian specimens only and forms a sister clade to all previously known $P$. leucophlebia clades. According to O'Brien et al. (2009), members of clades I and II have $P$. aphthosatype venation, which was also observed in one of the Estonian specimens from clade I. However, another Estonian specimen of clade I has a reticulate vein pattern characteristic of typical $P$. leucophebia in Europe (Vitikainen 1994), and this feature is also shared by all the specimens of clade IV (Fig. S2B). Further research is required to determine whether clades I and II represent new taxa previously unknown in Europe (O'Brien et al. 2009), as well as to elucidate their specific relationships with P. leucophlebia s. str. 
Diversity of the Peltigera taxa in different habitats

On the basis of substrate and habitat preferences, the analysed Peltigera taxa clustered into distinct ecological groups that correspond well to previous observations from other regions (e.g. HoltanHartwig 1993; Vitikainen 1994; Goward et al. 1995; Miadlikowska et al. 2003). The group of mesophytic species (e.g. P. praetextata, P. degenii, P. membranacea, P. polydactyla) were typically found in humid and sheltered sites including eutrophic forests, and the second group of more xerophytic species (e.g. $P$. didactyla, $P$. ponojensis, $P$. neckerii, $P$. rufescens) were typically found at exposed and often disturbed sites including dunes, alvars, and roadsides, but also oligotrophic pine forests with relatively open canopies. Most of the xerophytic taxa also exhibited clear preferences for specific soil properties. For example, $P$. ponojensis, $P$. leucophlebia, and $P$. "neorufescens" preferred calcareous nutrient-rich soils while $P$. aphthosa, $P$. extenuata, and $P$. malacea preferred nutrient-poor acidic soils. These and other habitat preferences were clearly visualized in the ordination diagrams (Figs 4-6).

The assemblage of Peltigera taxa in Estonian eutrophic forests differed significantly from that in all other habitats except for park stands. The similarity in species composition between these two habitat types is not surprising considering that the tree species composition and the canopy structure of moderately managed park stands in Estonia tend to resemble those of broad-leaved deciduous forests and are also known to provide a refugium for a number of forest-specific plant species (Liira et al. 2012). A number of the Peltigera species found in eutrophic and mesotrophic forests (e.g. P. collina, P. degenii, P. hymenina) are red-listed in Estonia (Randlane et al. 2008, Marmor et al. 2017) or at least regarded as hemerophobic (e.g. P. membranacea, P. neopolydactyla) (Trass et al. 1999). Also some rare Peltigera species that were not encountered (e.g. $P$. horizontalis) are known to prefer shaded habitats and occur almost exclusively on large deciduous trees in old-growth forests (Vitikainen 2007). In addition, some of the new taxa identified in this study (e.g. P. "neocanina", P. aff. "neocanina") were confined to sheltered forest environments. The regional rarity of these taxa in Estonia is undoubtedly linked to the general scarcity of old-growth deciduous stands in the present forest landscape (Lõhmus et al. 2004; Marmor et al. 2017).

In xeric habitats the diversity of Peltigera was the lowest in alvar grasslands and on acidic soils in oligotrophic forests while higher diversity was found from in roadside grasslands and dunes. Cyanolichen diversity is often the highest on sub-neutral substrates as many cyanolichens are quite sensitive to acidification (Rikkinen 2015). The relatively low soil pH of oligotrophic pine forests is clearly not optimal for several Peltigera taxa, even though some species (e.g. P. extenuata, P. didactyla s.lat., $P$. rufescens, $P$. malacea, $P$. aphthosa) do particularly well in this habitat. Dunes supported the high diversity of Peltigera species, presumably partly because of the highly variable Ca content of sand (Fig. S4E) but also because of favourable light conditions and weak competition from vascular plants (Jun and Rozé 2005; Ketner-Oostra et al. 2012; Jüriado et al. 2016). Also the relatively high Peltigera diversity in roadside habitats may be largely explained by the presence of limestone as limestone gravel is widely used for road construction in Estonia. Both roadsides and dunes are affected by relatively high levels of disturbance and human activity. Periodic removal of trees from dunes (Riksen et al. 2006; Jüriado et al. 2016) and mowing of roadside meadows (Parr and Way 1988) is needed for the long-term preservation of these habitats and the species diversity of their terricolous lichen communities. 
One previously undocumented feature found in this study is the existence of a relatively species-poor but very characteristic Peltigera community of alvar grasslands. Alvar grasslands are in many respects extreme habitats which are subjected to high environmental stress and considerable natural disturbance. The thin soil over monolithic rock is highly susceptible to extreme drought in summer, frost-induced soil movements in winter, and frequent small-scale flooding in spring (Rosén 1982; Ott et al. 1997). Because of calcareous base rock, alvar soils are rich in inorganic nutrients (Ca, Mg, P, K) (Fig. S4B-E). Additionally, the common occurrence of terricolous cyanobacteria may promote nitrogen availability (Büdel et al. 2014). The only frequent Peltigera species at alvar sites were the two putative taxa $P$. "neorufescens" and $P$. "neorufescens" agg. III. These lichens tolerate well grazing and other land use practices, which has modified Estonian alvars over recent millennia (Pärtel et al. 2005, 2007). They represent an interesting new addition to the long list of lichens characterizing alvar habitats (Fröberg 1988; Ott et al. 1996, 1997; Leppik et al. 2013, 2015). Unfortunately, in recent decades, habitat loss and degradation, mainly caused by ongoing changes in land use practices (Rosén and Bakker 2005), have started pose serious threat to alvars and their unique biota (Helm et al. 2006; Kasari et al. 2016). Effective conservation of alvar communities must involve promotion of lichen growth by suppressing shrubs and herbs via grazing or other means, and by allowing recurrent small-scale soil disturbances (Leppik et al. 2013, 2015).

In conclusion, our study revealed high, previously unrecognized diversity within the genus Peltigera in Estonia. Several undescribed species are confined to specific habitat types, including threatened alvar grasslands and deciduous broad-leaved forests. These results emphasize the potential importance of cryptic fungal diversity. It is evident that lichen surveys relying solely on phenotype characteristics can easily underestimate the true diversity of Peltigera taxa within given regions and habitat types. Continuing habitat loss threatens the diversity of Peltigera not only in pristine natural habitats (e.g. forests, dunes) but also in semi-natural habitat types, including alvar grasslands.

\section{Acknowledgments}

Financial support was received from the European Union's Horizon 2020 research and innovation programme under the Marie Sklodowska-Curie grant agreements No 659070 and No 705777 . M. Jylhä is acknowledged for indispensable assistance in laboratory work. Special thanks are due to E. Oja, A. Suija, P. Degtjarenko, J. Liira, M.-L. Kämärä, A. Palo, and T. Randlane for collecting some of the specimens. We are grateful to anonymous reviewers for their valuable comments on the manuscript. E. Jaigma is acknowledged for revising the English text of the manuscript.

\section{References}

Anstett DN, O'Brien H, Larsend EW, McMullin RT, Fortina MJ (2013) Dispersal analysis of three Peltigera species based on landscape genetics data. Mycology 4:187-195 
Aragón G, Belinchón R, Martínez I, Prieto M (2013) Estimating epiphytic lichen richness by single families in Mediterranean forests. Forest Ecol Manag 310:187-193

Benson S, Coxson DS (2002) Lichen Colonization and Gap Structure in Wet-Temperate Rainforests of Northern Interior British Columbia. Bryologist 105:673-692

Büdel B, Colesie C, Green TGA, Grube M, Lázaro Suau R, Loewen-Schneider K, Maier S, Peer T, Pintado A, Raggio J, Ruprecht U, Sancho LG, Schroeter B, Türk R, Weber B, Wedin M, Westberg M, Williams L, Zheng $L$ (2014) Improved appreciation of the functioning and importance of biological soil crusts in Europe - the Soil Crust International project (SCIN). Biodivers Conserv 23:1639-1658

Campbell J, Fredeen AL (2004) Lobaria pulmonaria abundance as an indicator of macrolichen diversity in interior cedar-hemlock forests of east-central British Columbia. Can J Bot 82:970-982

Campbell J, Bradfield GE, Prescott CE, Fredeen AL (2010) The influence of overstorey Populus on epiphytic lichens in subboreal spruce forests of British Columbia. Can J Forest Res 40:143-154

Costello MJ, May RM, Stork NE (2013) Can We Name Earth's Species Before They Go Extinct? Science 339:413-416

Costello MJ, Wilson S, Houlding B (2012) Predicting Total Global Species Richness Using Rates of Species Description and Estimates of Taxonomic Effort. Syst Biol 61:871-883

Cousins SAO, Auffret AG, Lindgren J, Tränk L (2015) Regional-scale land-cover change during the 20th century and its consequences for biodiversity. AMBIO 44:17-27

Divakar PK, Leavitt SD, Molina MC, Del-Prado R, Lumbsch HT, Crespo A (2016) A DNA barcoding approach for identification of hidden diversity in Parmeliaceae (Ascomycota): Parmelia sensu stricto as a case study. Bot J Linn Soc 180:21-29

Ellis CJ (2012) Lichen epiphyte diversity: A species, community and trait-based review. Perspect Plant Ecol 14:131-152

Ellis CJ (2013) A risk-based model of climate change threat: hazard, exposure, and vulnerability in the ecology of lichen epiphytes. Botany 91:1-11

Ellis CJ, Coppins BJ (2007) 19th century woodland structure controls stand-scale epiphyte diversity in present-day Scotland. Divers Distrib 13:84-91

Eriksson O, Cousins SAO, Bruun HH (2002) Land-use history and fragmentation of traditionally managed grasslands in Scandinavia. J Veg Sci 13:743-748

Fedrowitz K, Kuusinen M, Snäll T (2012) Metapopulation dynamics and future persistence of epiphytic cyanolichens in a European boreal forest ecosystem. J Appl Ecol 49:493-502

Fröberg L (1988) Calcicolous lichens and their ecological preferences on the Great Alvar of Öland. Acta Phytogeogr Suec 76:47-52

Galloway DJ (2000) The lichen genus Peltigera (Peltigerales: Ascomycota) in New Zealand. Tubinga 11:1-45 
Geiser LH, Neitlich PN (2007) Air pollution and climate gradients in western Oregon and Washington indicated by epiphytic macrolichens. Environl Pollut 145:203-218

Goffinet B, Hastings RI (1995) Two new sorediate taxa of Peltigera. Lichenologist 27:43-58

Goffinet B, Miadlikowska J (1999) Peltigera phyllidiosa (Peltigeraceae, Ascomycotina), a new species from the Southern Appalachians corroborated by ITS sequences. Lichenologist 31:247-255

Goffinet B, Miadlikowska J, Goward T (2003) Phylogenetic Inferences Based on nrDNA Sequences Support Five Morphospecies within the Peltigera didactyla Complex (Lichenized Ascomycota). Bryologist 106:349-364

Goward T, Arsenault A (2000) Cyanolichens and conifers: implications for global conservation. Forest

Snow and Landscape Research 75:303-318

Goward T, Goffinet B, Vitikainen O (1995) Synopsis of the genus Peltigera (lichenized Ascomycetes) in British Columbia, with a key to the North American species. Can J Bot 73:91-111

Hall TA (1999) BioEdit: a user-friendly biological sequence alignment editor and analysis program for Windows 95/98/NT. Nucl Acid S 41:95-98

Han L-F, Zheng T-X, Guo S-Y (2015) A new species in the lichen genus Peltigera from northern China based on morphology and DNA sequence data. Bryologist 118:46-53

Hawksworth DL (2012) Global species numbers of fungi: Are tropical studies and molecular approaches contributing to a more robust estimate? Biodivers Conserv 21:2425-2433

Helm A, Hanski I, Pärtel M (2006) Slow response of plant species richness to habitat loss and fragmentation. Ecol Lett 9:72-77

Hodkinson BP, Allen JL, Forrest LL et al. (2014) Lichen-symbiotic cyanobacteria associated with Peltigera have an alternative vanadium-dependent nitrogen fixation system. Eur J Phycol 49:11-19

Holtan-Hartwig J (1993) The lichen genus Peltigera, exclusive of the P. canina group, in Norway. Sommerfeltia 15:1-77

Huelsenbeck JP, Ronquist F (2001) MrBayes: Bayesian inference of phylogenetic trees. Bioinformatics $17: 754-755$

Huelsenbeck JP, Larget B, Miller RE, Ronquist F (2002) Potential applications and pitfalls of Bayesian inference of phylogeny. Syst Biol 51:673-688

Huelsenbeck JP, Ronquist F, Nielsen R, Bollback JP (2001) Bayesian inference of phylogeny and its impact on evolutionary biology. Science 294:2310-2314

Jääskeläinen K, Pykälä J, Rämä H, Vitikainen O, Haikonen V, Högnabba F, Lommi S, Puolasmaa A (2010) Lichens. In: Rassi P, Hyvärinen E, Juslén A, Mannerkoski I (eds), The 2010 Red List of Finnish Species. Ministry of the Environment, Helsinki, pp 278-310

Johansson BG, Petersson J (eds) (2016) Gotlands flora band 1. SBF-förlag, Uppsala 
Jun R, Rozé F (2005) Monitoring bryophytes and lichens dynamics in sand dunes: example on the French Atlantic coast, In: Herrier JL et al. (eds), Dunes and estuaries. Int. Conf. on Nat. Rest. Practices in Eur. Coastal Habitats, VLIZ Special Publication, pp 291-313

Jüriado I, Kämärä M-L, Oja E (2016) Environmental factors and ground disturbance affecting the composition of species and functional traits of ground layer lichens on grey dunes and dune heaths of Estonia. Nord J Bot 34:244-255

Jüriado I, Leppik E, Lõhmus P, Randlane T, Liira J (2015) Epiphytic lichens on Juniperus communis - an unexplored component of biodiversity in threatened alvar grassland. Nord J Bot 33:128-139

Kaasalainen U, Fewer DP, Jokela J, Wahlsten M, Sivonen K, Rikkinen J (2013) Lichen species identity and diversity of cyanobacterial toxins in symbiosis. New Phytol 198:647-651

Kasari L, Saar L, de Bello F, Takkis K, Helm A (2016) Hybrid ecosystems can contribute to local biodiversity conservation. Biodivers Conserv 25:3023-3041

Katoh K, Standley DM (2013) MAFFT Multiple Sequence Alignment Software Version 7, Improvements in Performance and Usability. Mol Biol Evol 30:772-780

Ketner-Oostra R, Aptroot A, Jungerius PD, Sýkora KV (2012) Vegetation succession and habitat restoration in Dutch lichen-rich inland drift sands. Tuexenia 32:245-268

Kuussaari M, Bommarco R, Heikkinen RK, Helm A, Krauss J, Lindborg R, Öckinger E, Pärtel M, Pino J, Rodá F, Stefanescu C, Teder T, Zobel M, Steffan-Dewenter I (2009) Extinction debt: a challenge for biodiversity conservation. Trends Ecol Evol 24: 564-71

Leavitt SD, Fernández-Mendoza F, Pérez-Ortega S, Sohrabi M, Divakar PK, Lumbsch HT, St Clair LL (2013) DNA barcode identification of lichen-forming fungal species in the Rhizoplaca melanophthalma speciescomplex (Lecanorales, Lecanoraceae), including five new species. MycoKeys 7:1-22

Lendemer JC, O'Brien H (2011) How do you reconcile molecular and non-molecular datasets? A case study where new molecular data prompts a revision of Peltigera hydrothyria s.I. in North America and the recognition of two species. Opuscula Philolichenum, 9:99-110

Leppik E, Jüriado I, Suija A, Liira J (2013) The conservation of ground layer lichen communities in alvar grasslands and the relevance of substitution habitats. Biodivers Conserv 22:591-614

Leppik E, Jüriado I, Suija A, Liira J (2015) Functional ecology of rare and common epigeic lichens in alvar grasslands. Fungal Ecol 13:66-76

Librado P, Rozas J (2009) DnaSP v5: A software for comprehensive analysis of DNA polymorphism data. Bioinformatics 25:1451-2

Liira J, Lõhmus K, Tuisk E (2012) Old manor parks as potential habitats for forest flora in agricultural landscapes of Estonia. Biol Conserv 146:144-154

Liška J, Zdeněk P, Slavíková Š (2008) Checklist and Red List of lichens of the Czech Republic. Preslia 80:151-182

Lõhmus A, Kohv K, Palo A, Viilma K (2004) Loss of old-growth, and the minimum need for strictly protected forests in Estonia. Ecol Bull 51:401-411 
Lumbsch HT, Leavitt SD (2011) Goodbye morphology? A paradigm shift in the delimitation of species in lichenized fungi. Fungal Divers 50:59-72

Lumbsch, HT, Ahti T, Altermann S et al (2011) One hundred new species of lichenized fungi: a signature of undiscovered global diversity. Phytotaxa 18:1-127

Magain N, Miadlikowska J, Goffinet B, Sérusiaux E, Lutzoni F (2017) Macroevolution of specificity in cyanolichens of the genus Peltigera section Polydactylon (Lecanoromycetes, Ascomycota). Syst Biol 66:74-99

Magain N, Sérusiaux E, Zhurbenko MP, Lutzoni F, Miadlikowska J (2016) Disentangling the Peltigera polydactylon species complex by recognizing two new taxa, $P$. polydactylon subsp. udeghe and $P$. seneca. Herzogia 29:514-528

Manoharan-Basil SS, Miadlikowska J, Goward T, Andresson O, Miao VPW (2016) Peltigera islandica, a new cyanolichen species in section Peltigera ('P. canina group'). Lichenologist 48:451-467

Marmor L, Randlane T, Jüriado I, Saag A (2017) Host tree preferences of red-listed epiphytic lichens in Estonia. Baltic Forestry 23:364-373

Martínez I, Burgaz AR, Vitikainen O, Escuredo A (2003) Distribution patterns in the genus Peltigera Willd. Lichenologist 35:301-323

McCune B, Mefford MJ (2001) PC-ORD. Multivariate analysis of ecological data, version 6. MjM Software Design, Gleneden Beach

Miadlikowska J, Lutzoni F (2000) Phylogenetic Revision of the Genus Peltigera (Lichen-Forming Ascomycota) Based on Morphological, Chemical, and Large Subunit Nuclear Ribosomal DNA Data. Int J Plant Sci 161:925-958

Miadlikowska J, Lutzoni F, Goward T, Zoller S, Posada D (2003) New approach to an old problem: Incorporating signal from gap-rich regions of ITS and rDNA large subunit into phylogenetic analyses to resolve the Peltigera canina species complex. Mycologia 95:1181-1203

Miadlikowska J, Richardson D, Magain N, Ball B, Anderson F, Cameron R, Lendemer J, Truong C, Lutzoni $F$ (2014) Phylogenetic placement, species delimitation, and cyanobiont identity of endangered aquatic Peltigera species (lichen-forming Ascomycota, Lecanoromycetes). Am J Bot 101:1141-1156

Miller MA, Pfeiffer W, Schwartz T (2010) Creating the CIPRES Science Gateway for inference of large phylogenetic trees. In: Proceedings of the Gateway Computing Environments Workshop (GCE), 14 Nov. 2010, New Orleans, LA, pp 1-8

Müller K, Quandt D, Müller J, Neinhuis C (2005) PhyDE ${ }^{\circledR}$ 0.995: Phylogenetic Data Editor. www.phyde.de

O'Brien HE, Miadlikowska J, Lutzoni F (2009) Assessing reproductive isolation in highly diverse communities of the lichen-forming fungal genus Peltigera. Evolution 63:2076-2086

Öster M (2008) Low congruence between the diversity of Waxcap (Hygrocybe spp.) fungi and vascular plants in semi-natural grasslands. Basic Appl Ecol 9:514-522 
Ott S, Elders U, Jahns HM (1996) Vegetation of the rock-alvar of Gotland I. Microhabitats and succession. Nova Hedwigia 63:433-470

Ott S, Elders U, Jahns HM (1997) Vegetation of the rock-alvar of Gotland II. Microclimate of lichen-rich habitats. Nova Hedwigia 64:87-101

Page A L, Miller R H, Keeney D R (1982) Methods of soil analysis, part 2. Chemical and microbiological properties. Am Soc Agr, Madison, WI, USA

Parr TW, Way JM (1988) Management of Roadside Vegetation: The Long-Term Effects of Cutting. J Appl Ecol 25:1073-1087

Pärtel M, Bruun HH, Sammul M (2005) Biodiversity in temperate European grasslands: origin and conservation. In: Lillak R, Viiralt V, Linke A, Geherman V (eds) Integrating efficient grassland farming and biodiversity. Estonian Grassland Society, Tartu. Grassland Science in Europe, Vol 10:1-14

Pärtel M, Helm A, Reitalu T, Liira J, Zobel M (2007) Grassland diversity related to the Late Iron Age human population density. J Ecol 95:574-582

Penn O, Privman E, Ashkenazy H, Landan G, Graur D, Pupko T (2010) GUIDANCE: a web server for assessing alignment confidence scores. Nucleic Acids Res 38:23-28

Pimm SL, Raven PH (2017) The Fate of the World's Plants. Trends Ecol Evol 32:317-320

Posada D (2008) jModelTest: phylogenetic model averaging. Mol Biol Evol 25:1253-1256

Rambaut A, Drummond AJ (2009) Tracer v1.5. Available: http://beast.bio.ed.ac.uk/Tracer

Ramírez-Fernández L, Zúñiga C, Méndez MA, Carú M, Orlando J (2013) Genetic diversity of terricolous Peltigera cyanolichen communities in different conservation states of native forest from southern Chile. Int Microbiol 16:243-252

Randlane T, Jüriado I, Suija A, Lõhmus P, Leppik E (2008) Lichens in the new red list of Estonia. Folia Cryptog Estonica 44:113-120

Raukas A (ed) (1995) Estonia Nature. Eesti Entsüklopeediakirjastus, Tallinn

Richardson DHS, Cameron RP (2004) Cyanolichens: their response to pollution and possible management strategies for their conservation in northeastern North America. Northeast Nat 11:1-22 Rikkinen J (2015) Cyanolichens. Biodivers Conserv 24:973-993

Rikkinen J (2017) Symbiotic cyanobacteria in lichens. In: Grube M et al. (eds) Algae and Cyanobacteria in Symbiosis, World Scientific Publishing, pp 147-167

Riksen M, Ketner-Oostra R, van Turnhout C, Nijssen M, Goossens D, Jungerius PD, Spaan W (2006) Will we lose the last active drift sands of western Europe? The origin and development of the inland driftsand ecotype in the Netherlands. Landscape Ecol 21: 431-447

Rosén E (1982) Vegetation development and sheep grazing in limestone grasslands of south Öland, Sweden. Acta Phytogeogr Suec 72:1-104

Rosén E, Bakker JP (2005) Effects of agri-environment schemes on scrub clearance, livestock grazing and plant diversity in a low-intensity farming system on Öland, Sweden. Basic Appl Ecol 6:195-204 
Rubio-Salcedo M, Psomas A, Prieto M, Zimmermann NE, Martínez I (2016) Case study of the implications of climate change for lichen diversity and distributions. Biodivers Conserv 26:1121-1141 Sang A, Teder T, Helm A, Pärtel M (2010) Indirect evidence for an extinction debt of grassland butterflies half century after habitat loss. Biol Conserv 143:1405-1413

Schulte EE (1995) Recommended soil organic matter tests. In: Sims JT, Wolf A (eds), Recommended soil testing procedures for the northeastern United States. Northeast Reg Bull 493:47-56

Smith CW, Aptroot A, Coppins BJ, Fletcher A, Gilbert OL, James PW, Wolseley PA (2009) The Lichens of Great Britain and Ireland. British Lichen Society, London

Spellerberg IF, Fedor PJ (2003) A tribute to Claude Shannon (1916-2001) and a plea for more rigorous use of species richness, species diversity and the 'Shannon-Wiener' Index. Global Ecol Biogeogr 12:177179

Stöver BC, Müller KF (2010) TreeGraph 2: Combining and visualizing evidence from different phylogenetic analyses. BMC Bioinformatics 11:7

Šmilauer P, Lepš J (2014) Multivariate analysis of ecological data using Canoco 5. Cambridge Univ Press Trass H, Vellak K, Ingerpuu N (1999) Floristical and ecological properties for identifying of primeval forests in Estonia. Ann Bot Fennici 36:67-80

Vitikainen O (1994) Taxonomic revision of Peltigera (lichenized Ascomycotina) in Europe. Acta Bot Fennica 152:1-96

Vitikainen O (2007) Peltigeraceae. Nordic Lichen Flora 3:113-129

Werth S, Wagner HH, Gugerli F, Holderegger R, Csencsics D, Kalwij MJ, Scheidegger C (2006) Quantifying dispersal and establishment limitation in a population of epiphytic lichen. Ecology 87:2037-2046

White TJ, Bruns TD, Le, S, Taylor JW (1990) Amplification and direct sequencing of fungal ribosomal RNA genes for phylogenetics, In: Innis MA, Gelfand DH, Sninsky JJ, White TJ (eds) PCR protocols: a guide to methods and applications. New York, NY, USA: Academic Press Inc, pp 315-322

Yahr R, Schoch CL, Dentinger BTM (2016) Scaling up discovery of hidden diversity in fungi: impacts of barcoding approaches. Phil Trans R Soc B 371: 20150336, http://dx.doi.org/10.1098/rstb.2015.0336

Zúñiga C, Leiva D, Ramírez-Fernández L, Carú M, Yahr R, Orlando J (2015) Phylogenetic Diversity of Peltigera Cyanolichens and Their Photobionts in Southern Chile and Antarctica. Microbes Environ 30:172-179 
Table 1. List of the Peltigera taxa found in Estonia in this study. The number of fungal ITS sequences, different genotypes, and collection localities (sites) is given for each taxon. The last column (Ord) shows which of the taxa were included in the ordination analyses (+).

\begin{tabular}{|c|c|c|c|c|}
\hline Taxa & Sequences & Genotypes & Sites & Ord \\
\hline Peltigera aphthosa (L.) Willd. & 4 & 3 & 4 & + \\
\hline \multicolumn{5}{|l|}{ Peltigera canina (L.) Willd. s. lat. } \\
\hline P. canina & 9 & 2 & 6 & + \\
\hline P. canina II & 16 & 3 & 13 & + \\
\hline P. canina III & 26 & 5 & 20 & + \\
\hline Peltigera collina (Ach.) Schrad. & 1 & 1 & 1 & \\
\hline Peltigera degenii Gyeln. & 3 & 1 & 3 & + \\
\hline \multicolumn{5}{|l|}{ Peltigera didactyla (With.) J.R.Laundon s. lat. } \\
\hline P. didactyla I & 4 & 2 & 3 & + \\
\hline P. didactyla II & 6 & 4 & 6 & + \\
\hline P. didactyla III & 3 & 2 & 2 & \\
\hline Peltigera extenuata (Nyl. ex Vain.) Lojka & 7 & 1 & 3 & + \\
\hline Peltigera "fuscoponojensis"1 & 7 & 3 & 5 & + \\
\hline Peltigera hymenina (Ach.) Delise & 3 & 1 & 3 & + \\
\hline Peltigera islandica Goward \& Manoharan-Basil & 1 & 1 & 1 & \\
\hline Peltigera lepidophora (Vain.) Bitter. & 2 & 2 & 2 & \\
\hline \multicolumn{5}{|l|}{ Peltigera leucophlebia (Nyl.) Gyeln. s. lat. } \\
\hline P. leucophlebia I & 2 & 1 & 2 & \\
\hline P. leucophlebia IV & 4 & 2 & 4 & + \\
\hline Peltigera malacea (Ach.) Funck & 10 & 2 & 8 & + \\
\hline Peltigera membranacea (Ach.) Nyl. & 4 & 3 & 3 & + \\
\hline Peltigera neckeri Hepp ex Müll.Arg. & 10 & 5 & 8 & + \\
\hline Peltigera aff. "neocanina" & 9 & 5 & 6 & + \\
\hline Peltigera "neocanina"1 & 2 & 2 & 1 & \\
\hline Peltigera neopolydactyla (Gyeln.) Gyeln. & 1 & 1 & 1 & \\
\hline \multicolumn{5}{|l|}{ Peltigera "neorufescens" agg. } \\
\hline P. "neorufescens" agg. I & 2 & 2 & 2 & \\
\hline P. "neorufescens" agg. II & 5 & 5 & 4 & + \\
\hline P. "neorufescens" agg. III & 8 & 6 & 3 & + \\
\hline Peltigera "neorufescens" 1 & 29 & 24 & 12 & + \\
\hline Peltigera polydactylon (Neck.) Hoffm. & 17 & 3 & 10 & + \\
\hline \multicolumn{5}{|l|}{ Peltigera ponojensis Gyeln. s. lat. } \\
\hline P. ponojensis I & 9 & 6 & 7 & + \\
\hline P. ponojensis II & 8 & 6 & 7 & + \\
\hline Peltigera praetextata (Flörke ex Sommerf.) Zopf & 13 & 1 & 11 & + \\
\hline Peltigera rufescens (Weiss) Humb. & 27 & 20 & 14 & + \\
\hline
\end{tabular}

${ }^{1}$ Taxa defined by Miadlikowska et al. (2003) 
Table 2. Number of sequenced Peltigera specimens from different substrates (ground, rock, tree) and habitat types; number of taxa (S); and value of Shannon diversity index (H) for each habitat type.

\begin{tabular}{llllll}
\hline Habitat & Ground & Rock & Tree & S & H \\
\hline Oligotrophic forests & 27 & 1 & - & 10 & 2.09 \\
Eutrophic forests & 21 & 9 & 44 & 18 & 2.37 \\
Park stands & 15 & 10 & - & 14 & 2.47 \\
Alvars & 43 & - & - & 10 & 1.49 \\
Dunes & 47 & - & - & 15 & 2.46 \\
Roadsides & 30 & 5 & - & 14 & 2.48 \\
\hline Total & 183 & 25 & 44 & & \\
Average & & & & 13.5 & 2.22 \\
\hline
\end{tabular}




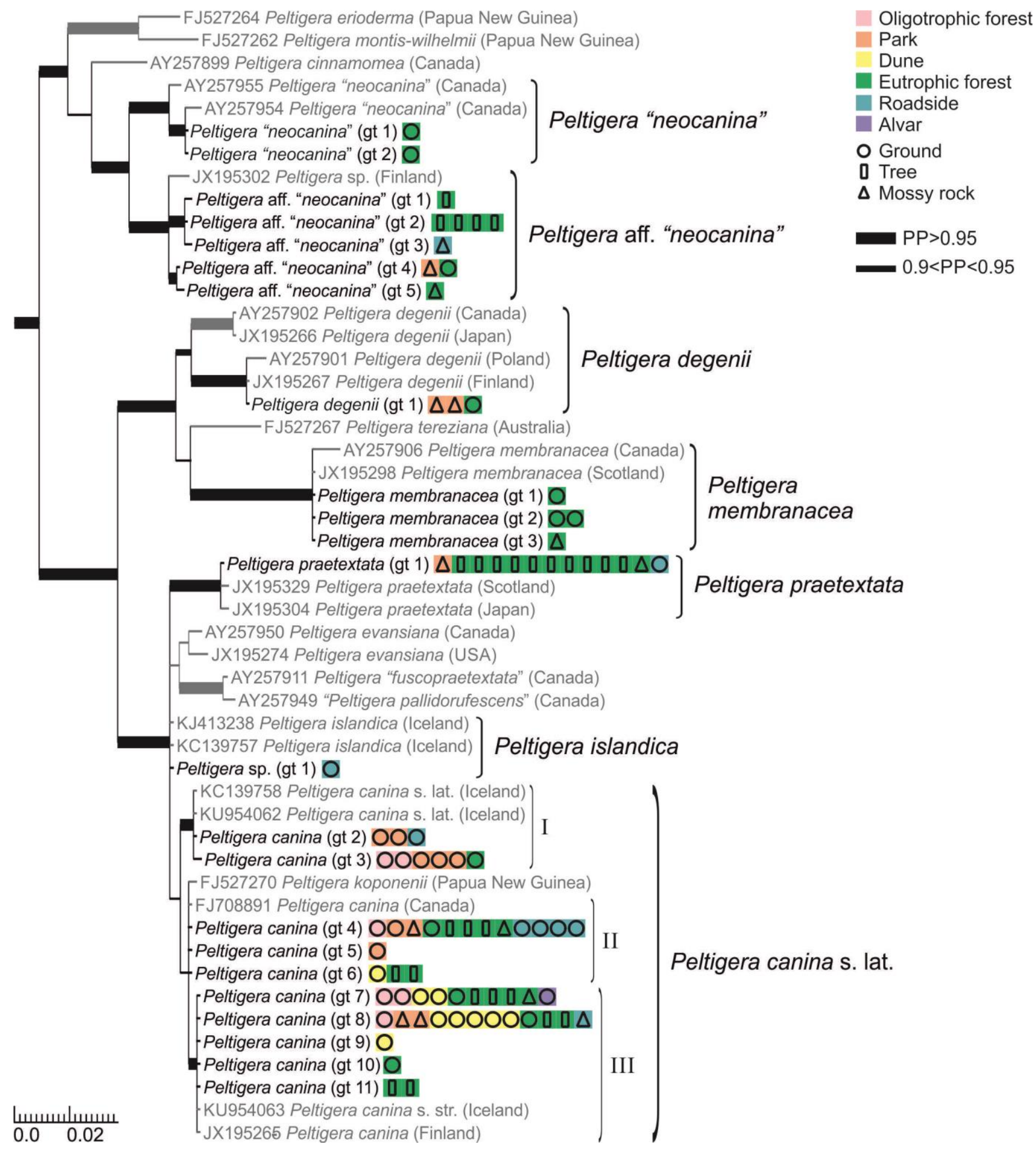

Figure 1. Phylogeny constructed of the ITS-sequences of the Peltigera canina-group (Peltigera section Peltigera). Support for each clade is indicated by branch thickness. Each square represents a specimen of the respective genotype, with the colour indicating its habitat and the symbol indicating its substrate. The sequences in grey were downloaded from the NCBI GeneBank (specimens from outside of Estonia). The outgroup (not shown) included Peltigera kristinssonii (AY257891), P. frigida (AY257893), P. continentalis (يY257890), and P. isidiofora (J095107). 


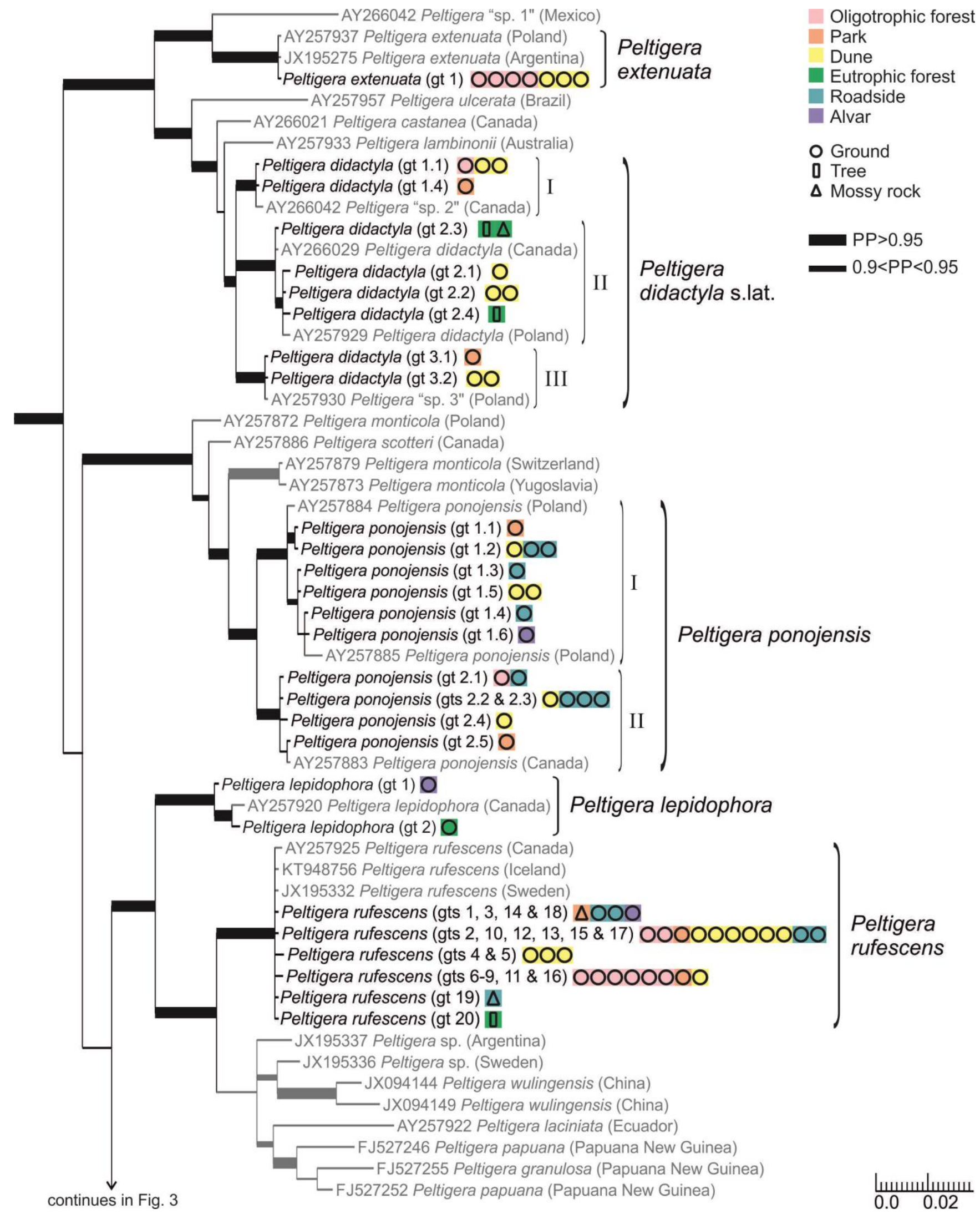

Figure 2. Phylogeny constructed of the ITS-sequences of the Peltigera rufescens-group (Peltigera section Peltigera, the tree is continued in Fig. 3). Support for each clade is indicated by branch thickness. Each square represents a specimen of the respective genotype, with the colour indicating its habitat 
and the symbol indicating its substrate. The sequences in grey were downloaded from the NCBI GeneBank (specimens from outside of Estonia). The outgroup (not shown) included Peltigera canina

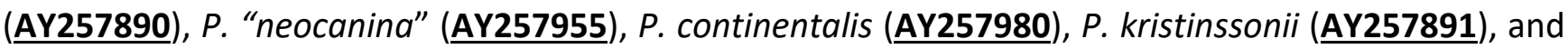
P. frigida (AY257893).

Oligotrophic forest

Park

Dune

Eutrophic forest

Roadside

Alvar

O Ground

0 Tree

$\Delta$ Mossy rock

DP $>0.95$

$0.9<P P<0.95$
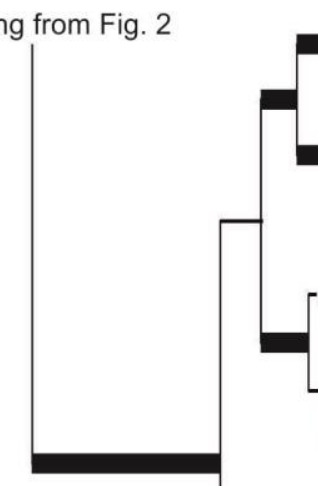

Peltigera sp. (gt 1.1)

Peltigera sp. (gt 1.2) $\Delta$

Peltigera sp. (gt 2.1)

Peltigera sp. (gt 2.2) $\mathrm{O}$

-Peltigera sp. (gt 2.4) O II

Peltigera sp. (gt 2.5) O

Peltigera sp. (gt 2.6) O

[Peltigera sp. (gt 3.2) $\mathrm{OO}$

[Peltigera sp. (gt 3.1) $\mathrm{O}$

- Peltigera sp. (gt 3.4) O

- Peltigera sp. (gt 3.3 \& 3.5) 000

- Peltigera sp. (gt 3.6) O

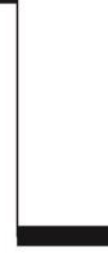

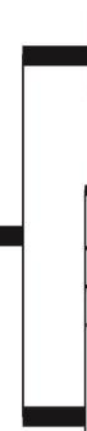

AY257910 Pe

Peltigera "fuscoponojensis" (gt 1 )

- Peltigera "fuscoponojensis" (gt 2)

-Peltigera "fuscoponojensis" (gt 3) O

Peltigera sp.

(P. "neorufescens" agg.)

III

-Peltigera "neorufescens" (gt 16)

LAY257916 "Peltigera neorufescens" (Canada)

-Peltigera "neorufescens" (gt 17) 000

Peltigera "neorufescens" (gt 21) O

-KT861422 Peltigera "neorufescens" (Iceland)

Peltigera "neorufescens" (gt 2) $\mathrm{OO}$

-Peltigera "neorufescens" (gt 3) O

-Peltigera "neorufescens" (gt 4) $\mathrm{OO}$

-Peltigera "neorufescens" (gt 5) 0

-Peltigera "neorufescens" (gt 6) 0

- Peltigera "neorufescens" (gt 18) O

-Peltigera "neorufescens" (gt 20) O

- Peltigera "neorufescens" (gt 23) O

Peltigera "neorufescens"

[Peltigera "neorufescens" (gt 22) $\mathrm{O}$

- Peltigera "neorufescens" (gt 8) 0

Peltigera

"fuscoponojensis"

Peltigera "neorufescens" (gt 9) $\mathrm{O}$

Peltigera "neorufescens" (gt 7) $\mathrm{O}$

-Peltigera "neorufescens" (gt 10) $\mathrm{OO}$

Peltigera "neorufescens" (gts 11 \& 13) 000

-Peltigera "neorufescens" (gt 12) O

-Peltigera "neorufescens" (gt 14) O

- Peltigera "neorufescens" (gt 15) 0

- Peltigera "neorufescens" (gt 19) O

Peltigera "neorufescens" (gt 24) $\mathrm{O}$

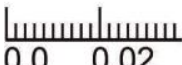

Figure 3. Part of the phylogeny constructed of the ITS-sequences of the Peltigera rufescens-group (Peltigera section Peltigera, the tree is continued from Fig. 2). Support for each clade is indicated by branch thickness. Each square represents a specimen of the respective genotype, with the colour indicating its habitat and the symbol indicating its substrate. The sequences in grey were downloaded from the NCBI GeneBank (specimens from outside of Estonia). 


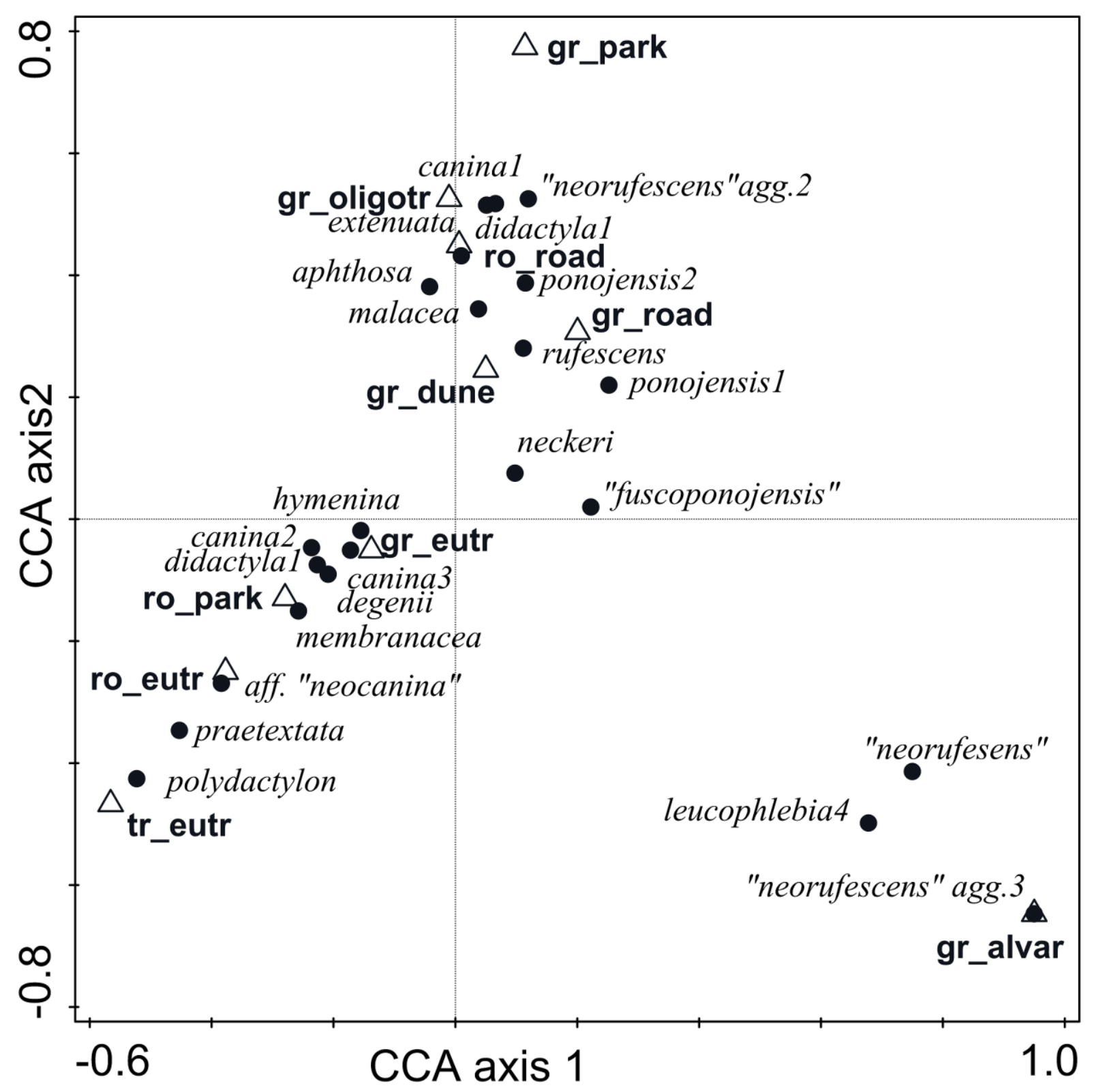

Figure 4. Peltigera taxa (dots) and environmental variables (triangles) in the bi-plot of the canonical correspondence analysis (CCA) of the first and second axes. The Peltigera species typically found in alvar habitats are situated below on the right and the species preferring tree bases and logs in eutrophic forests are below on the left. Some species growing both on tree bases in woody habitats and on soil in open dune grasslands are in the middle while the ground-dwelling Peltigera species preferring xeric habitats cluster in the upper part of the diagram. Abbrevations: 'gr_alvar' = ground in alvars, 'gr_park' = ground in park stands, 'gr_oligotr' = ground in oligotrophic forests, 'gr_road' = ground in roadside grasslands, 'gr_dune' = ground on dunes, 'gr_eutr' = ground in eutrophic forests, 'ro_eutr' = rocks in eutrophic forests, 'ro_park' = rocks in park stands, 'tr_eutr' = trees in eutrophic forests. The statistically important variables in the forward selection of environmental variables are 'gr_alvar' and 'tr_eutr'. 


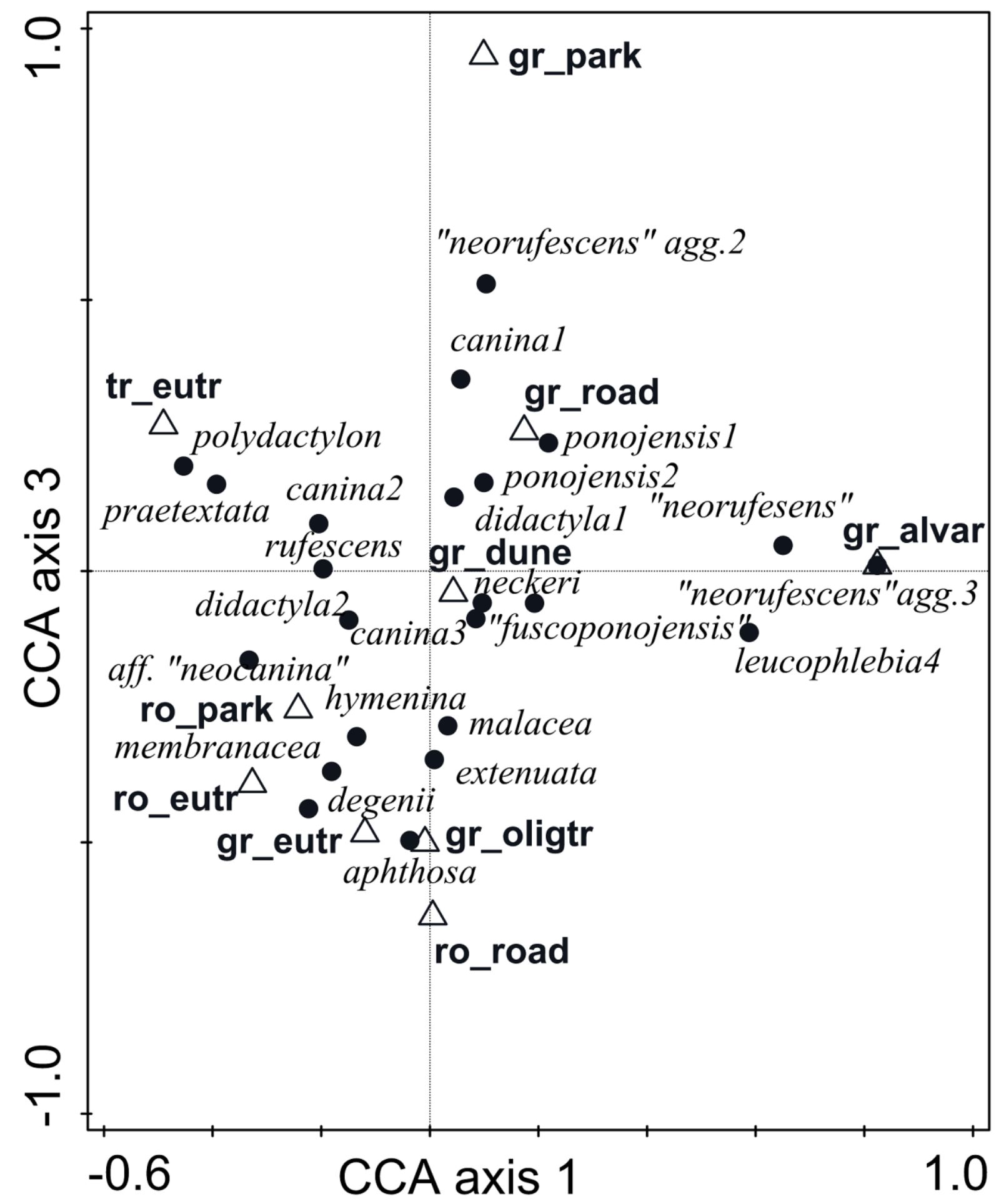

Figure 5. Peltigera taxa (dots) and environmental variables (triangles) in the bi-plot of the canonical correspondence analysis (CCA) of the first and third axes. Differences in the habitat preferences of Peltigera species from xeric habitats are shown with the Peltigera species from oligotrophic pine forests in the lower part of the diagram and the species from more open habitats in the upper part. Abbrevations as in Fig. 4. 


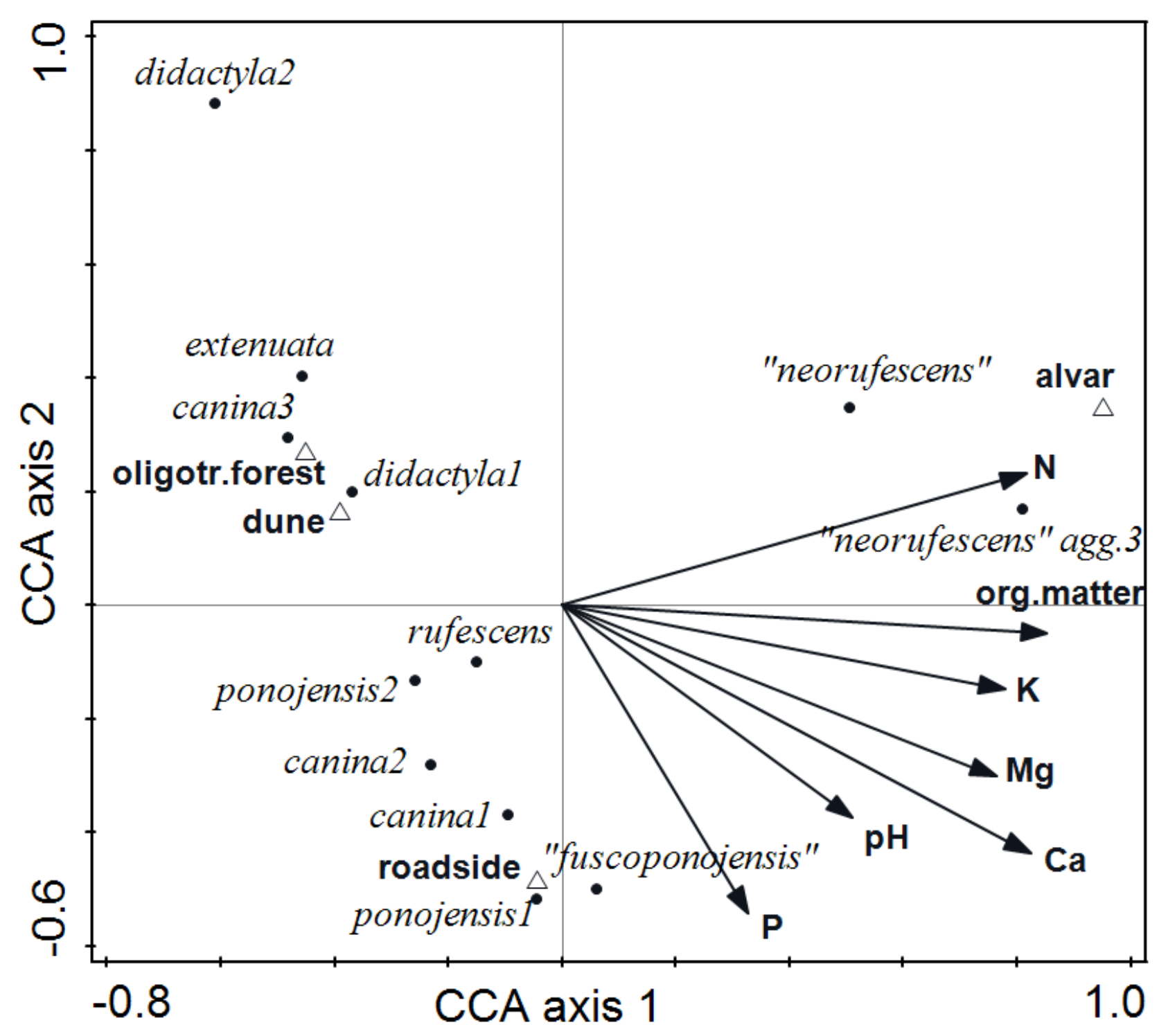

Figure 6. Terricolous Peltigera taxa (section Peltigera) (dots) and environmental variables (nominal variables as triangles) in the bi-plot of the canonical correspondence analysis (CCA) of the first and second axes. The species typical of alvar soils are on the right; the species from roadside grasslands and other nutrient rich sites are in the lower part, while species of acidic nutrient-poor soils are above on the left. Oligotr. forest = oligotrophic forest, ' $\mathrm{N}$ ' = soil $\mathrm{N}$ content, ' $\mathrm{K}$ '= soil $\mathrm{K}$ content, ' $\mathrm{Mg}$ ' = soil $\mathrm{Mg}$ content, ' $\mathrm{Ca}$ ' = soil $\mathrm{Ca}$ content, ' $\mathrm{P}$ ' = soil $\mathrm{P}$ content, 'Org. matter' = soil organic matter content, ' $\mathrm{pH}$ ' = soil $\mathrm{pH}$. 
Electronic supplementary material: Fungal Ecology

Inga Jüriado a, b, ${ }^{*}$, Ulla Kaasalainen ${ }^{c}$ and Jouko Rikkinen ${ }^{b, c}$

Specialist taxa restricted to threatened habitats contribute significantly to the regional diversity of Peltigera (Lecanorales, Ascomycota) in Estonia

${ }^{a}$ Institute of Ecology and Earth Sciences, University of Tartu, Lai 38/40 Tartu 51005, Estonia.

${ }^{b}$ Department of Biosciences, University of Helsinki, P.O. Box 65, 00014, Helsinki, Finland.

${ }^{\mathrm{C}}$ Finnish Museum of Natural History, University of Helsinki, P.O. Box 7, Helsinki, Finland.

*Correspondence: Inga Jüriado; Institute of Ecology and Earth Sciences, University of Tartu, Lai 38/40

Tartu 51005, Estonia; E-mail: inga.juriado@ut.ee; telephone: + 3725168846 

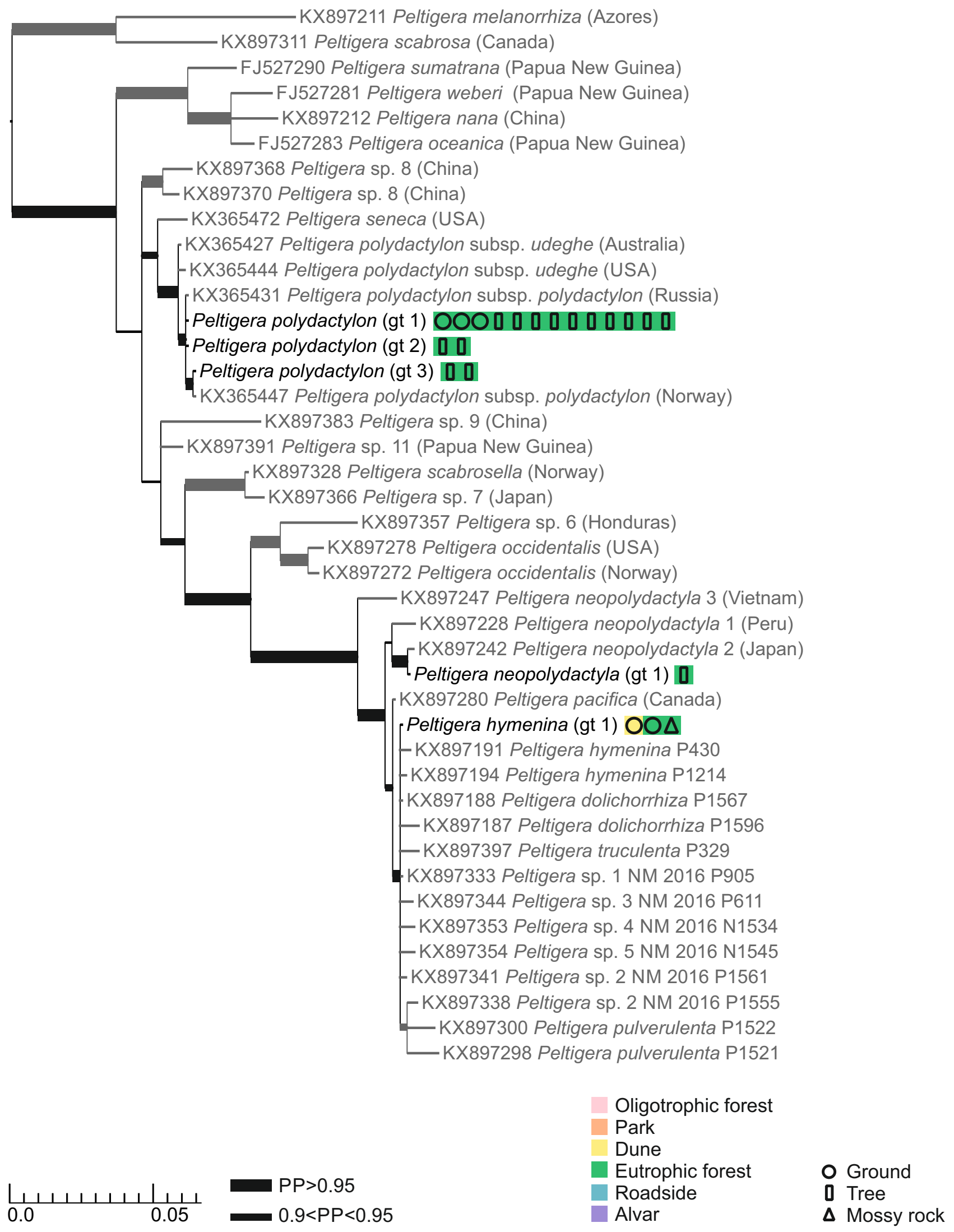

Figure S1. Phylogeny constructed of the ITS-sequences of the polydactyloid and dolichorhizzoid group (Magain et al. 2017) within the Peltigera section Polydactylon. The support for each clade is reflected in the thickness of the branch. Each square represents a specimen of the respective genotype indicating the habitat (color) and substrate (symbol). Grey specimens are not from Estonia but downloaded from the NCBI GeneBank. 


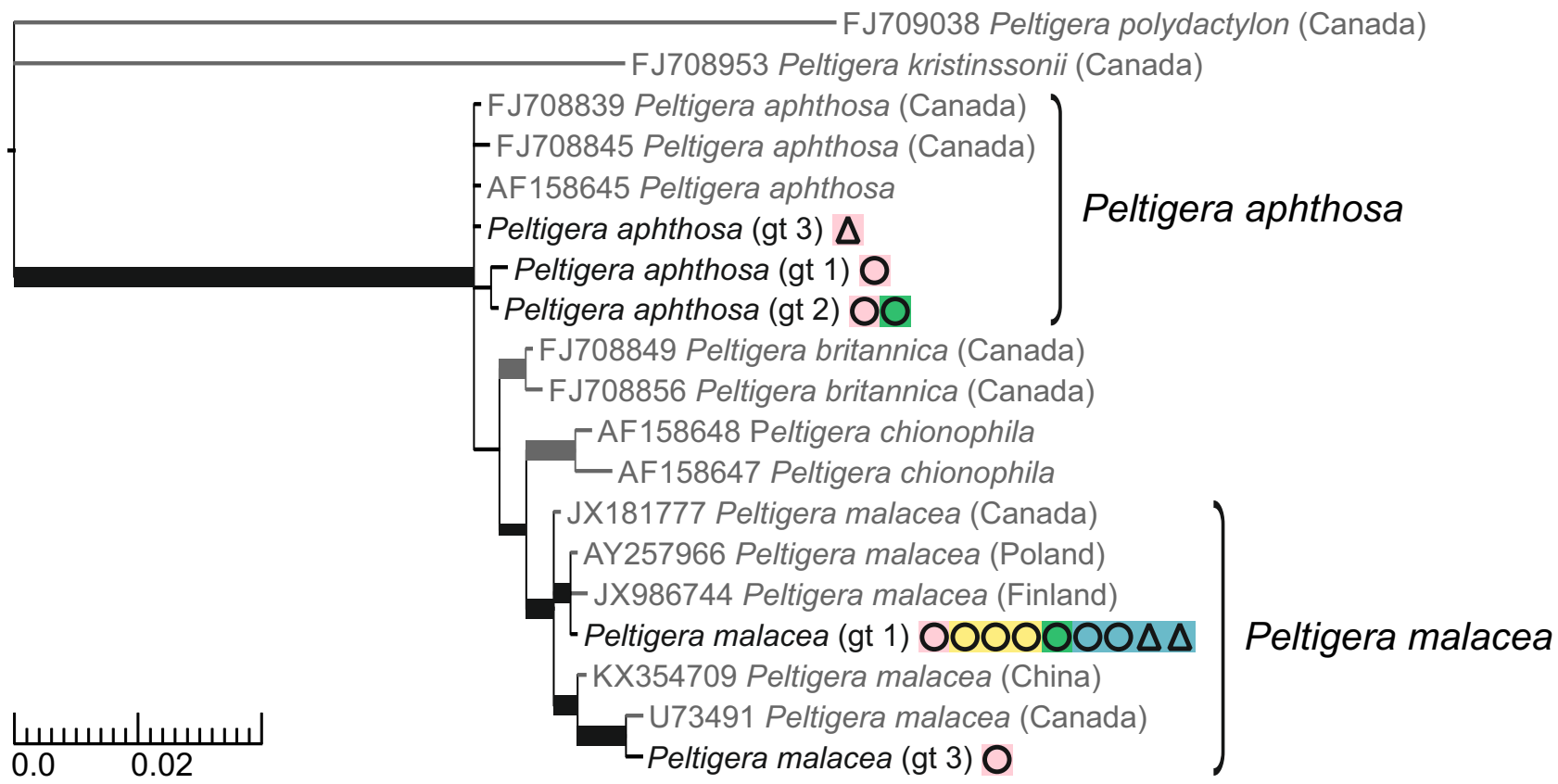

B

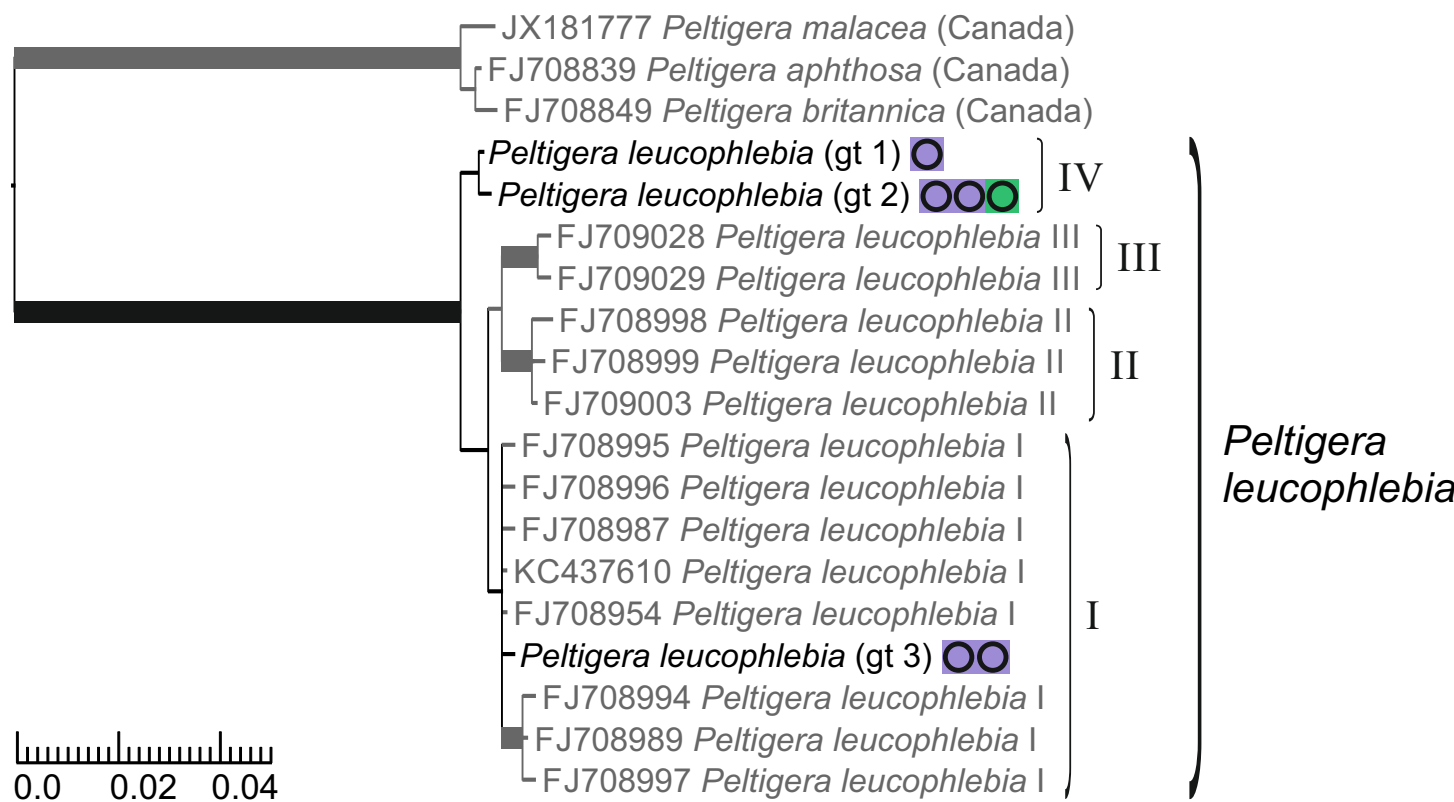

Oligotrophic forest

Park

Dune

Eutrophic forest

Roadside

O Ground

Alvar

D Tree

$\mathrm{PP}>0.95$

$\Delta$ Mossy rock

$0.9<P P<0.95$

Figure S2. Phylogeny constructed of the ITS-sequences of the Peltigera section A) Peltidea and B) Chloropeltigera. The support for each clade is reflected in the thickness of the branch. Each square represents a specimen of the respective genotype indicating the habitat (color) and substrate (symbol). Grey specimens are not from Estonia but downloaded from the NCBI GeneBank. 


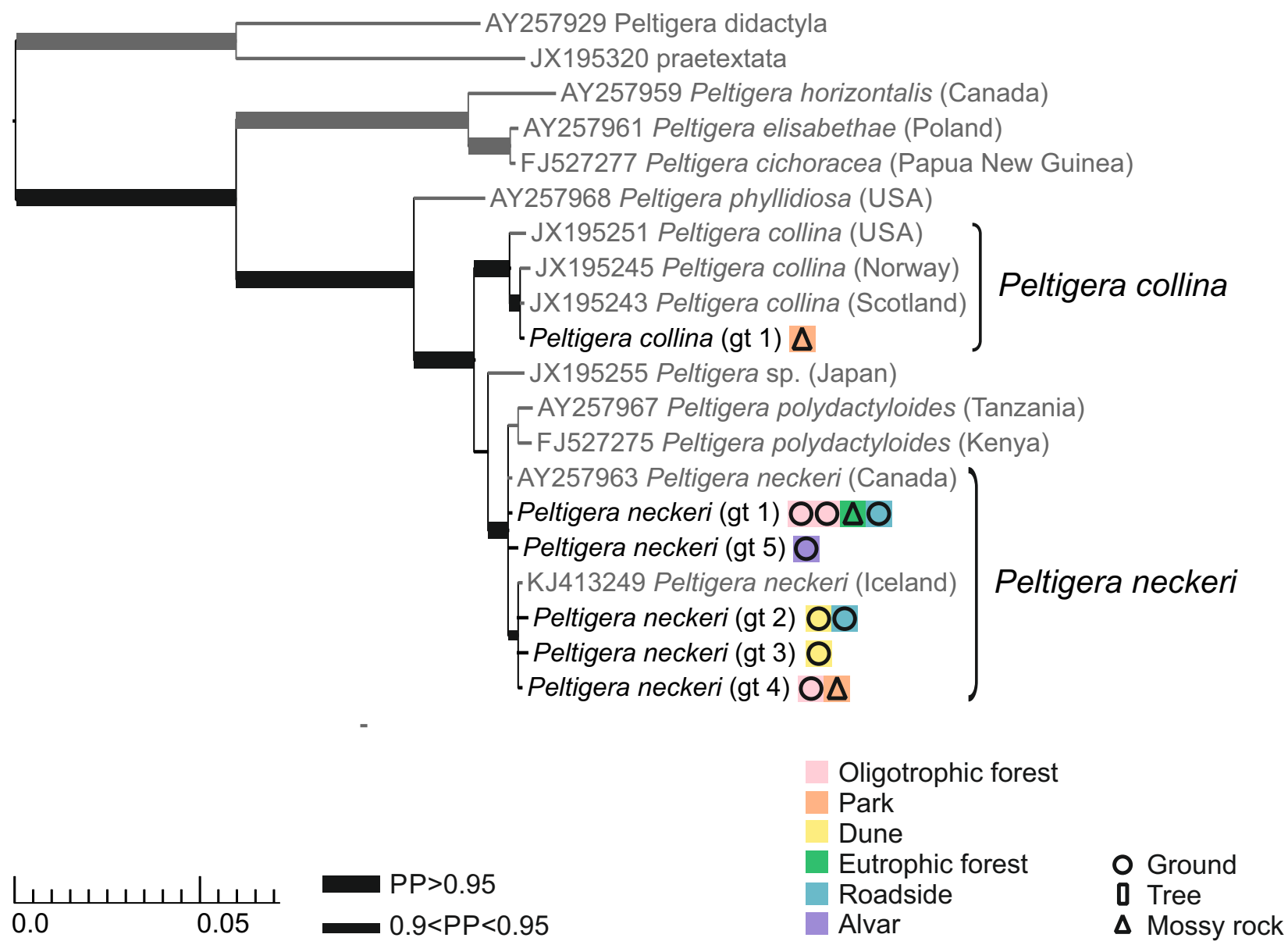

Figure S3. Phylogeny constructed of the ITS-sequences of the Peltigera section Horizontales. The support for each clade is reflected in the thickness of the branch. Each square represents a specimen of the respective genotype indicating the habitat (color) and substrate (symbol). Grey specimens are not from Estonia but downloaded from the NCBI GeneBank. 

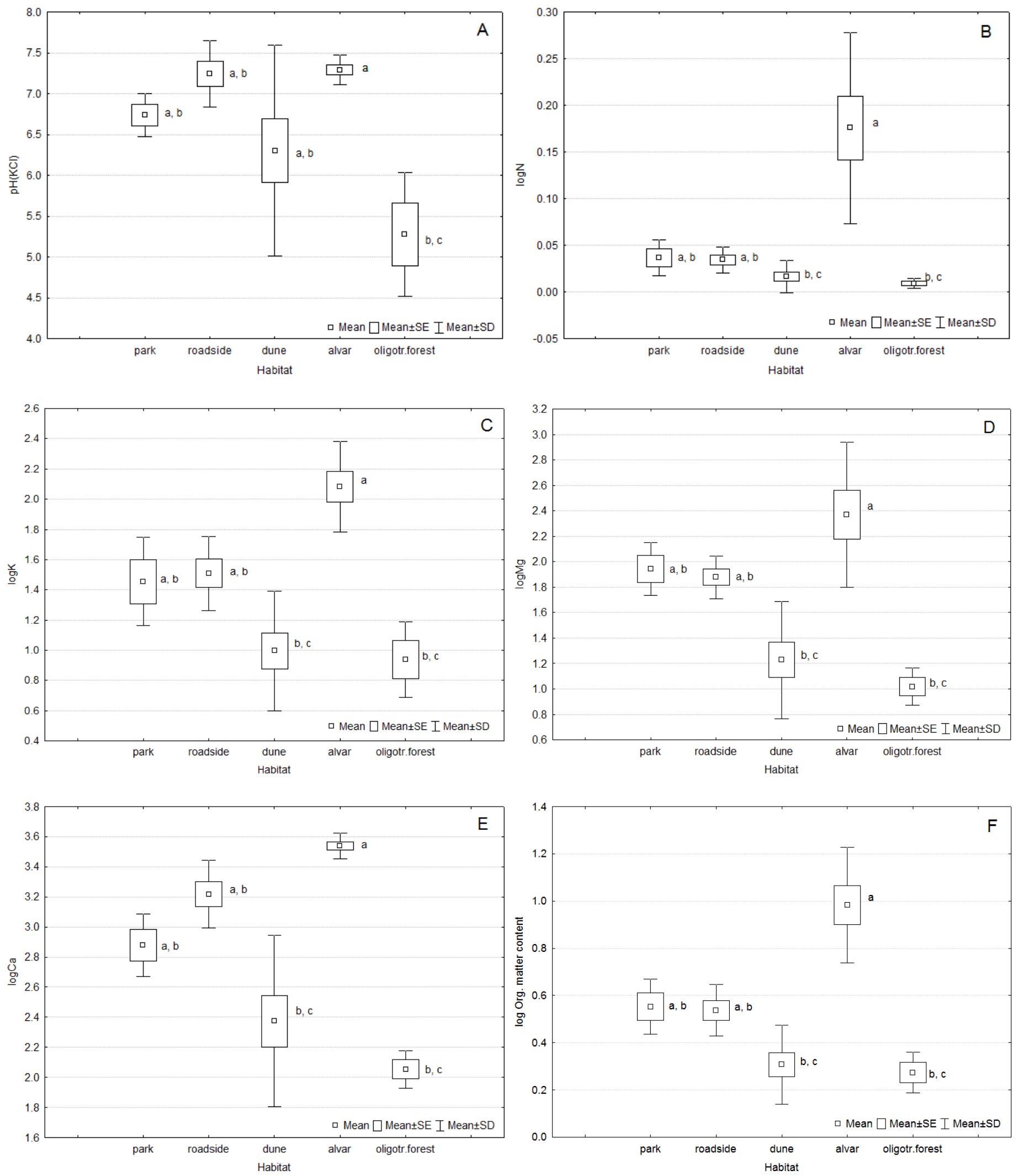


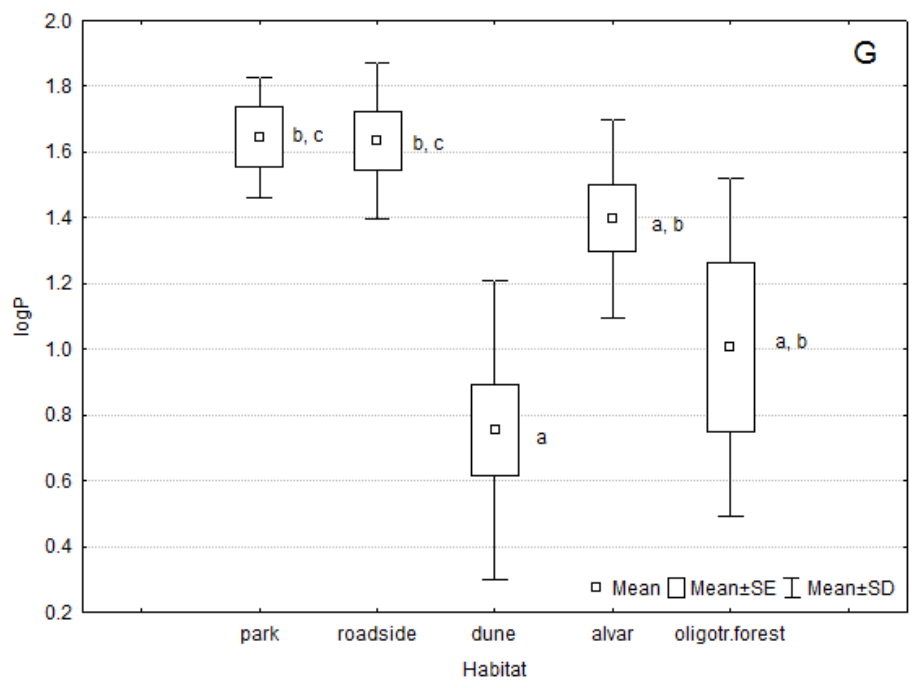

Figure S4A-G. Mean values of $\mathrm{pH}$ soil, N, K, Mg, Ca, K and P organic matter content of studied habitat types. Kruskal-Wallis test for soil $\mathrm{pH}(\mathrm{A}) \mathrm{H}(4, \mathrm{~N}=35)=11.293, \mathrm{p}=0.0023$; for soil $\mathrm{N}(\mathrm{B}) \mathrm{H}=25.685, \mathrm{p}<0.0001$; for soil $\mathrm{K}(\mathrm{C}) \mathrm{H}(4, \mathrm{~N}=35)=25.126, \mathrm{p}<0.0001$; for soil Mg (D) H (4, N = 35) = 22.253, p = 0.0002); for soil Ca (E) H (4, $\mathrm{N}$ $=35)=27.814, \mathrm{p}<0.0001$; $\operatorname{organic}$ matter $(\mathrm{F}) \mathrm{H}(4, \mathrm{~N}=35)=25.597, \mathrm{p}<0.0001$ and $\mathrm{P}(\mathrm{G}) \mathrm{H}(4, \mathrm{~N}=35)=18.365$, $p=0.001)$. Homogeneity groups of multiple comparisons are presented with letters. 
Electronic supplementary material: Fungal Ecology

Inga Jüriado, Ulla Kaasalainen and Jouko Rikkinen. Specialist taxa restricted to threatened habitats contribute significantly to the regional diversity of Peltigera (Lecanorales, Ascomycota) in Estonia.

Table S1. List of the Peltigera taxa found in Estonia; GenBank accession numbers and number of ITS clade according to the phylogenetic analyses (see Figures 1-3 and S1-S3). Information about collection site (county and locality in Estonia), substratum and habitat type, collector and specimen ID in TU (University of Tartu, Natural History Museum). Abbrevations: ' $C$ ' = county, 'NP' = national park, 'LKA', 'MKA' = nature reserves, 'gr_alvar' = ground in alvars, 'gr_park' = ground in park stands, 'gr_oligotr' = ground in oligotrophic forests, 'gr_road' = ground in roadside grasslands, 'gr_dune' = ground on dunes, 'gr_eutr' = ground in eutrophic forests, 'ro_eutr' $=$ rocks in eutrophic forests, 'ro_park' $=$ rocks in park stands, 'tr_eutr' = trees in eutrophic forests.

\begin{tabular}{|c|c|c|c|c|c|}
\hline $\begin{array}{l}\text { GenBank } \\
\text { accession no }\end{array}$ & Taxa & Clade & County /Locality & $\begin{array}{l}\text { Substratum } \\
\text { /Habitat }\end{array}$ & $\begin{array}{l}\text { Collector / Specimen } \\
\text { ID }\end{array}$ \\
\hline LT852805 & Peltigera aphthosa & & Põlva C., Ihamaru LKA & gr_oligotr & E. Oja \\
\hline LT852806 & Peltigera aphthosa & & Valga C., Otepää Parish & gr_oligotr & V. Liiv (TU73090) \\
\hline LT852807 & Peltigera canina & 1 & Võru C., Hargla & gr_eutr & I. Jüriado \\
\hline LT852808 & Peltigera canina & 1 & Võru C., Hargla & gr_park & I. Jüriado \\
\hline$\underline{\text { LT852809 }}$ & Peltigera canina & I & Võru C., Võru & gr_road & I. Jüriado \\
\hline$\underline{\text { LT852810 }}$ & Peltigera canina & 1 & Võru C., Hargla & gr_park & I. Jüriado \\
\hline ㄴT852811 & Peltigera canina & I & Võru C., Hargla & gr_park & I. Jüriado \\
\hline LT852812 & Peltigera canina & I & Ida-Viru C., Rannapungerja & gr_oligotr & I. Jüriado \\
\hline LT852813 & Peltigera canina & I & Ida-Viru C., Rannapungerja & gr_oligotr & I. Jüriado \\
\hline LT852814 & Peltigera canina & 1 & Ida-Viru C., Lohusuu & gr_oligotr & I. Jüriado \\
\hline$\underline{\text { LT852815 }}$ & Peltigera canina & I & Ida-Viru C., Lohusuu & gr_oligotr & I. Jüriado \\
\hline LTT852816 & Peltigera canina & II & Võru C., Hargla & gr_park & I. Jüriado \\
\hline
\end{tabular}




\begin{tabular}{|c|c|c|c|c|c|}
\hline LT852817 & Peltigera canina & II & Võru C., Hargla & gr_park & I. Jüriado \\
\hline LT852818 & Peltigera canina & II & Tartu C., Järvselja & ro_park & I. Jüriado \\
\hline LT852819 & Peltigera canina & II & Tartu C., Järvselja & gr_road & I. Jüriado \\
\hline LT852820 & Peltigera canina & II & Tartu C., Järvselja & gr_road & I. Jüriado \\
\hline LT852821 & Peltigera canina & II & Lääne-Viru C., Suurekivi & tr_eutr & I. Jüriado \\
\hline LT852822 & Peltigera canina & II & Pärnu C., Kihnu & gr_eutr & A. Suija \\
\hline$\underline{\text { LT852823 }}$ & Peltigera canina & II & Põlva C., Ihamaru LKA & tr_eutr & E. Oja \\
\hline LT852824 & Peltigera canina & II & Hiiu C., Tõnupsi & gr_dune & M.-L. Kämärä \\
\hline LTR52825 & Peltigera canina & II & Ida-Viru., Lohusuu & gr_oligotr & I. Jüriado \\
\hline$\underline{\text { LT852826 }}$ & Peltigera canina & II & Lääne-Viru C., Lahemaa NP, Karula & ro_eutr & I. Jüriado (TU58785) \\
\hline LT852827 & Peltigera canina & II & Ida-Viru C., Puhatu LKA & tr_eutr & A. Suija (TU39796) \\
\hline LT852828 & Peltigera canina & III & Võru C., Vastse-Roosa & gr_oligotr & I. Jüriado \\
\hline$\underline{\text { LT852829 }}$ & Peltigera canina & III & Saare C., Eeriksaare & gr_dune & I. Jüriado \\
\hline$\underline{\text { LT852830 }}$ & Peltigera canina & III & Saare C., Eeriksaare & gr_dune & I. Jüriado \\
\hline LT852831 & Peltigera canina & III & Saare C., Eeriksaare & gr_dune & I. Jüriado \\
\hline LT852832 & Peltigera canina & III & Saare C., Eeriksaare & gr_dune & I. Jüriado \\
\hline LT852833 & Peltigera canina & III & Saare C., Harilaid & gr_dune & I. Jüriado \\
\hline LT852834 & Peltigera canina & III & Pärnu C.,Rannametsa & gr_oligotr & I. Jüriado \\
\hline LT852835 & Peltigera canina & III & Tartu C., Võnnu & ro_park & I. Jüriado \\
\hline LT852836 & Peltigera canina & III & Tartu C., Võnnu & ro_park & I. Jüriado \\
\hline LT852837 & Peltigera canina & III & Lääne-Viru C., Suurekivi & tr_eutr & I. Jüriado \\
\hline
\end{tabular}




\begin{tabular}{|c|c|c|c|c|c|}
\hline$\underline{\text { LT852838 }}$ & Peltigera canina & III & Saare C., Kihnu & gr_eutr & A. Suija \\
\hline LT852839 & Peltigera canina & III & Saare C., Kihnu & gr_eutr & P. Degtjarenko \\
\hline LT852840 & Peltigera canina & III & Hiiu C., Luidja & gr_dune & M.-L. Kämärä \\
\hline LT852841 & Peltigera canina & III & Saare C., Kiipsaare & gr_dune & M.-L. Kämärä \\
\hline LT852842 & Peltigera canina & III & Hiiu C., Tõnupsi & gr_dune & M.-L. Kämärä \\
\hline LT852843 & Peltigera canina & III & Rapla C., Pakamägi & tr_eutr & E. Oja \\
\hline LT852844 & Peltigera canina & III & Tartu C., Elva-Vitipalu MKA & tr_eutr & E. Oja \\
\hline LT852845 & Peltigera canina & III & Tartu C., Elva-Vitipalu MKA & tr_eutr & E. Oja \\
\hline LT852846 & Peltigera canina & III & Ida-Viru C., Smolnitsa MK & tr_eutr & I. Jüriado (TU46221) \\
\hline LT852847 & Peltigera canina & III & Ida-Viru C., Agusalu MKA & tr_eutr & A. Suija (TU39795) \\
\hline LT852848 & Peltigera canina & III & Põlva C., Suur-Taevaskoda & ro_eutr & T. Randlane \\
\hline LT852849 & Peltigera islandica & & Tartu C., Kambja Parish, Sulu village & gr_road & I. Jüriado \\
\hline LT852850 & Peltigera collina & & Saare C., Väike-Rahula & ro_park & I. Jüriado (TU45667) \\
\hline LT852851 & Peltigera degenii & & Lääne-Viru C., Lahemaa NP, Palmse & ro_park & I. Jüriado (TU58786) \\
\hline LT 852852 & Peltigera degenii & & Harju C., Lahemaa NP, Kalme & gr_eutr & A. Suija (TU45213) \\
\hline LT852853 & Peltigera degenii & & Lääne-Viru C., Lahemaa NP, Palmse & ro_park & T. Randlane \\
\hline LT852854 & Peltigera didactyla & I & Võru C., Vastse-Roosa & gr_oligotr & I. Jüriado \\
\hline LT852855 & Peltigera didactyla & I & Ida-Viru C., Kauksi & gr_dune & I. Jüriado \\
\hline LT852856 & Peltigera didactyla & I & Ida-Viru C., Kauksi & gr_dune & I. Jüriado \\
\hline LT852857 & Peltigera didactyla & 1 & Ida-Viru C., Alajõe & gr_park & J. Liira \\
\hline LT852858 & Peltigera didactyla & II & Saare C., Harilaid & gr_dune & I. Jüriado \\
\hline
\end{tabular}




\begin{tabular}{|c|c|c|c|c|c|}
\hline LT852859 & Peltigera didactyla & II & Hiiu C., Luidja & gr_dune & M.-L. Kämärä \\
\hline LT852860 & Peltigera didactyla & II & Ida-Viru C., Kauksi & gr_dune & I. Jüriado \\
\hline LT852861 & Peltigera didactyla & II & Valga C., Soontaga LKA & tr_eutr & E. Oja \\
\hline LT852862 & Peltigera didactyla & II & Põlva C., Väike-Taevaskoja & ro_eutr & T. Randlane \\
\hline LT852863 & Peltigera didactyla & II & Põlva C., Ihamaru LKA & tr_eutr & E. Oja \\
\hline LT852864 & Peltigera didactyla & III & Võru C., Hargla & gr_park & I. Jüriado \\
\hline LT852865 & Peltigera didactyla & III & Saare C., Harilaid & gr_dune & I. Jüriado \\
\hline$\underline{\text { LT852866 }}$ & Peltigera didactyla & III & Saare C., Harilaid & gr_dune & I. Jüriado \\
\hline LT852867 & Peltigera extenuata & & Võru C., Varstu Parish, Singa & gr_oligotr & I. Jüriado \\
\hline LT852868 & Peltigera extenuata & & Võru C., Varstu Parish, Singa & gr_oligotr & I. Jüriado \\
\hline LT852869 & Peltigera extenuata & & Võru C., Varstu Parish, Singa & gr_oligotr & I. Jüriado \\
\hline LT852870 & Peltigera extenuata & & Pärnu C., Rannametsa & gr_oligotr & I. Jüriado \\
\hline LT852871 & Peltigera extenuata & & Hiiu C., Tõrvanina & gr_dune & M.-L. Kämärä \\
\hline LT852872 & Peltigera extenuata & & Hiiu C., Tõrvanina & gr_dune & M.-L. Kämärä \\
\hline LT852873 & Peltigera extenuata & & Hiiu C., Tõrvanina & gr_dune & M.-L. Kämärä \\
\hline LT852874 & Peltigera fuscoponojensis & & Saare C., Eeriksaare & gr_dune & I. Jüriado \\
\hline LT852875 & Peltigera fuscoponojensis & & Saare C., Eeriksaare & gr_dune & I. Jüriado \\
\hline LT852876 & Peltigera fuscoponojensis & & Saare C., Eeriksaare & gr_dune & I. Jüriado \\
\hline LT852877 & Peltigera fuscoponojensis & & Saare C., Karala & gr_dune & I. Jüriado \\
\hline LT852878 & Peltigera fuscoponojensis & & Saare C., Katri & gr_alvar & I. Jüriado \\
\hline LT852879 & Peltigera fuscoponojensis & & Tartu C., Melliste & gr_road & I. Jüriado \\
\hline
\end{tabular}




\begin{tabular}{|c|c|c|c|c|c|}
\hline LT852880 & Peltigera fuscoponojensis & & Lääne-Viru C., Lahemaa NP, Käsmu & gr_eutr & T. Randlane \\
\hline LT852881 & Peltigera hymenina & & Pärnu C., Häädemeeste & gr_eutr & I. Jüriado \\
\hline LT852882 & Peltigera hymenina & & Hiiu C., Tõrvanina & gr_dune & M.-L. Kämärä \\
\hline LT852883 & Peltigera hymenina & & $\begin{array}{l}\text { Lääne-Viru C., Lahemaa NP, Vihula } \\
\text { Parish }\end{array}$ & ro_eutr & I. Jüriado (TU71624) \\
\hline LT852884 & Peltigera lepidophora & & Rapla C., Lipstu & gr_eutr & $\begin{array}{l}\text { I. Jüriado, A. Suija } \\
\text { (TU66438) }\end{array}$ \\
\hline LT852885 & Peltigera lepidophora & & Jõgeva C., Sopimetsa LKA & gr_alvar & A. Suija (TU45690) \\
\hline LT852886 & Peltigera leucophlebia & IV & Rapla C., Tõrma & gr_alvar & A. Suija (TU42656) \\
\hline LT852887 & Peltigera malacea & & Saare C., Odalätsi & gr_dune & I. Jüriado \\
\hline LT852888 & Peltigera malacea & & Saare C., Odalätsi & gr_dune & I. Jüriado \\
\hline LT852889 & Peltigera malacea & & Saare C., Odalätsi & gr_dune & I. Jüriado \\
\hline LT852890 & Peltigera malacea & & Harju C., Lahemaa NP, Kaberneeme & gr_eutr & A. Suija \\
\hline LT852891 & Peltigera malacea & & Järva C., Kahala & ro_road & A. Suija \\
\hline LT852892 & Peltigera malacea & & Järva C., Koigi Parish & ro_road & A. Suija (TU75719) \\
\hline LT852893 & Peltigera malacea & & Harju C., Väike-Pakri & gr_road & $\begin{array}{l}\text { E. Leppik, A. Suija } \\
\text { (TU67659) }\end{array}$ \\
\hline LT852894 & Peltigera malacea & & Põlva C., Piusa & gr_oligotr & A. Suija (TU68244) \\
\hline LT852895 & Peltigera malacea & & Tartu C., Lohkva & gr_road & T. Randlane \\
\hline LT852896 & Peltigera membranacea & & Lääne-Viru C., Lahemaa NP, Mohni & gr_eutr & I. Jüriado (TU58684) \\
\hline LT852897 & Peltigera membranacea & & Lääne-Viru C., Lahemaa NP, Mohni & gr_eutr & I. Jüriado (TU58678) \\
\hline LT852898 & Peltigera membranacea & & Lääne-Viru C., Lahemaa NP, Mohni & gr_eutr & I. Jüriado (TU58679) \\
\hline LT852899 & Peltigera membranacea & & Lääne-Viru C., Lahemaa NP, Mohni & ro_eutr & I. Jüriado (TU58685) \\
\hline
\end{tabular}




\begin{tabular}{|c|c|c|c|c|}
\hline$\underline{\text { LT852900 }}$ & Peltigera neckeri & Võru C., Vastse-Roosa & gr_oligotr & I. Jüriado \\
\hline LT852901 & Peltigera neckeri & Võru C., Vastse-Roosa & gr_oligotr & I. Jüriado \\
\hline LT852902 & Peltigera neckeri & Võru C., Vastse-Roosa & gr_oligotr & I. Jüriado \\
\hline LT852903 & Peltigera neckeri & Lääne C., Noarootsi Parish, Põõsaspea & gr_road & T. Randlane \\
\hline LT852904 & Peltigera neckeri & Tartu C., Kambja Parish, Sulu village & gr_road & I. Jüriado \\
\hline LT852905 & Peltigera neckeri & Saare C., Kiipsaare & gr_dune & M.-L. Kämärä \\
\hline LT852906 & Peltigera neckeri & Lääne C., Keibu & gr_dune & M.-L. Kämärä \\
\hline$\underline{\text { LT852907 }}$ & Peltigera neckeri & Lääne C., Osmussaar & gr_road & $\begin{array}{l}\text { I. Jüriado, A. Suija } \\
\text { (TU55488) }\end{array}$ \\
\hline$\underline{\text { LT852908 }}$ & Peltigera neckeri & Hiiu C., Sarve MKA & gr_alvar & $\begin{array}{l}\text { E. Leppik, I. Jüriado } \\
\text { (TU55487) }\end{array}$ \\
\hline LT852909 & Peltigera neckeri & Jõgeva C., Josua & ro_eutr & T. Randlane \\
\hline LT852910 & Peltigera neocanina & Võru C., Hargla & gr_eutr & I. Jüriado \\
\hline ㄴT852911 & Peltigera neocanina & Võru C., Hargla & gr_eutr & I. Jüriado \\
\hline LT852912 & Peltigera aff. neocanina & Lääne-Viru C., Lasila & tr_eutr & I. Jüriado \\
\hline LT852913 & Peltigera aff. neocanina & Lääne-Viru C., Lasila & tr_eutr & I. Jüriado \\
\hline LT852914 & Peltigera aff. neocanina & Lääne-Viru C., Suurekivi & tr_eutr & I. Jüriado \\
\hline LT852915 & Peltigera aff. neocanina & Rapla C., Lokuta & ro_eutr & E. Oja \\
\hline LT852916 & Peltigera aff. neocanina & Lääne-Viru C., Suurekivi & tr_eutr & I. Jüriado \\
\hline$\underline{\text { LT852917 }}$ & Peltigera aff. neocanina & Lääne-Viru C., Lasila & tr_eutr & I. Jüriado \\
\hline LT852918 & Peltigera aff. neocanina & Lääne-Viru C., NP, Mohni & gr_eutr & I. Jüriado (TU58683) \\
\hline LT852919 & Peltigera aff. neocanina & Lääne-Viru C., Lahemaa NP, Palmse & ro_park & T. Randlane \\
\hline LT852920 & Peltigera aff. neocanina & Põlva C., Taevaskoja & ro_eutr & T. Randlane \\
\hline
\end{tabular}




\begin{tabular}{|c|c|c|c|c|}
\hline LT852921 & Peltigera neopolydactyla & Ida-Viru C., Muraka LKA & tr_eutr & P. Lõhmus (TU47418) \\
\hline LT852922 & Peltigera neorufescens & Võru C., Võru & gr_road & I. Jüriado \\
\hline$\underline{\text { LT852923 }}$ & Peltigera neorufescens & Võru C., Võru & gr_road & I. Jüriado \\
\hline LT852924 & Peltigera neorufescens & Lääne C., Sillukse & gr_alvar & I. Jüriado \\
\hline$\underline{\text { LT852925 }}$ & Peltigera neorufescens & Lääne C., Sillukse & gr_alvar & I. Jüriado \\
\hline LT852926 & Peltigera neorufescens & Saare C., Muhu, Nõmmküla & gr_alvar & I. Jüriado \\
\hline$\underline{\text { LT852927 }}$ & Peltigera neorufescens & Saare C., Muhu, Tupenurme & gr_alvar & I. Jüriado \\
\hline LT852928 & Peltigera neorufescens & Saare C., Muhu, Tupenurme & gr_alvar & I. Jüriado \\
\hline$\underline{\text { LT852929 }}$ & Peltigera neorufescens & Saare C., Muhu, Tupenurme & gr_alvar & I. Jüriado \\
\hline$\underline{\text { LT852930 }}$ & Peltigera neorufescens & Saare C., Muhu, Üügu & gr_alvar & I. Jüriado \\
\hline LT852931 & Peltigera neorufescens & Saare C., Muhu, Üügu & gr_alvar & I. Jüriado \\
\hline$\underline{\text { LT852932 }}$ & Peltigera neorufescens & Saare C., Katri & gr_alvar & I. Jüriado \\
\hline LT852933 & Peltigera neorufescens & Saare C., Tammese & gr_alvar & I. Jüriado \\
\hline$\underline{\text { LT852934 }}$ & Peltigera neorufescens & Saare C., Atla & gr_alvar & I. Jüriado \\
\hline$\underline{\text { LT852935 }}$ & Peltigera neorufescens & Saare C., Atla & gr_alvar & I. Jüriado \\
\hline$\underline{\text { LT852936 }}$ & Peltigera neorufescens & Saare C., Lõo & gr_alvar & I. Jüriado \\
\hline$\underline{\text { LT852937 }}$ & Peltigera neorufescens & Saare C., Lõo & gr_alvar & I. Jüriado \\
\hline$\underline{\text { LT852938 }}$ & Peltigera neorufescens & Saare C., Lõo & gr_alvar & I. Jüriado \\
\hline$\underline{\text { LT852939 }}$ & Peltigera neorufescens & Tartu C., Melliste & gr_road & I. Jüriado \\
\hline$\underline{\text { LT852940 }}$ & Peltigera neorufescens & Saare C., Kaugatoma & gr_alvar & I. Jüriado \\
\hline LT852941 & Peltigera neorufescens & Saare C., Atla & gr_alvar & I. Jüriado \\
\hline
\end{tabular}




\begin{tabular}{|c|c|c|c|c|c|}
\hline LT852942 & Peltigera neorufescens & & Saare C., Atla & gr_alvar & I. Jüriado \\
\hline LT852943 & Peltigera neorufescens & & Saare C., Eeriksaare & gr_dune & I. Jüriado \\
\hline LT852944 & Peltigera neorufescens & & Saare C., Eeriksaare & gr_dune & I. Jüriado \\
\hline LT852945 & Peltigera neorufescens & & Saare C., Muhu, Üügu & gr_alvar & I. Jüriado \\
\hline LT852946 & Peltigera neorufescens & & Saare C., Muhu, Üügu & gr_alvar & I. Jüriado \\
\hline LT852947 & Peltigera neorufescens & & Saare C., Muhu, Üügu & gr_alvar & I. Jüriado \\
\hline LT852948 & Peltigera neorufescens & & Saare C., Muhu, Üügu & gr_alvar & I. Jüriado \\
\hline LT852949 & Peltigera neorufescens & & Saare C., Muhu, Tupenurme & gr_alvar & I. Jüriado \\
\hline LT852950 & Peltigera neorufescens & & Saare C., Muhu, Tupenurme & gr_alvar & I. Jüriado \\
\hline LT852951 & Peltigera neorufescens agg. & I & Pärnu C., Kilingi-Nõmme & gr_road & I. Jüriado \\
\hline LT852952 & Peltigera neorufescens agg. & 1 & Harju C., Pakri peninsula & ro_road & T. Randlane \\
\hline LT852953 & Peltigera neorufescens agg. & II & Pärnu C., Kilingi-Nõmme & gr_road & I. Jüriado \\
\hline LT852954 & Peltigera neorufescens agg. & II & Pärnu C., Kilingi-Nõmme & gr_road & I. Jüriado \\
\hline LT852955 & Peltigera neorufescens agg. & II & Tartu C., Nõgiaru & gr_park & T. Randlane \\
\hline$\underline{\text { LT852956 }}$ & Peltigera neorufescens agg. & II & Hiiu C., Tõrvanina & gr_dune & M.-L. Kämärä \\
\hline LT852957 & Peltigera neorufescens agg. & II & Ida-Viru C., Rannapungerja & gr_park & I. Jüriado \\
\hline LT852958 & Peltigera neorufescens agg. & III & Saare C., Muhu, Üügu & gr_alvar & I. Jüriado \\
\hline LT852959 & Peltigera neorufescens agg. & III & Saare C., Tammese & gr_alvar & I. Jüriado \\
\hline LT852960 & Peltigera neorufescens agg. & III & Saare C., Atla & gr_alvar & I. Jüriado \\
\hline LT852961 & Peltigera neorufescens agg. & III & Saare C., Tammese & gr_alvar & I. Jüriado \\
\hline LT852962 & Peltigera neorufescens agg. & III & Saare C., Atla & gr_alvar & I. Jüriado \\
\hline
\end{tabular}




\begin{tabular}{|c|c|c|c|c|c|}
\hline$\underline{\text { LT852963 }}$ & Peltigera neorufescens agg. & III & Saare C., Atla & gr_alvar & I. Jüriado \\
\hline LT852964 & Peltigera neorufescens agg. & III & Saare C., Muhu, Üügu & gr_alvar & I. Jüriado \\
\hline LT852965 & Peltigera neorufescens agg. & III & Saare C., Muhu, Üügu & gr_alvar & I. Jüriado \\
\hline LT852966 & Peltigera polydactylon & & Tartu C., Järvselja & gr_eutr & I. Jüriado \\
\hline LT852967 & Peltigera polydactylon & & Tartu C., Järvselja & gr_eutr & I. Jüriado \\
\hline LT852968 & Peltigera polydactylon & & Tartu C., Järvselja & gr_eutr & I. Jüriado \\
\hline LT852969 & Peltigera polydactylon & & Tartu C., Järvselja & tr_eutr & I. Jüriado \\
\hline LT852970 & Peltigera polydactylon & & Tartu C., Järvselja & tr_eutr & I. Jüriado \\
\hline LT852971 & Peltigera polydactylon & & Tartu C., Välgi LKA & tr_eutr & E. Oja \\
\hline LT852972 & Peltigera polydactylon & & Tartu C., Elva-Vitipalu MKA & tr_eutr & E. Oja \\
\hline LT852973 & Peltigera polydactylon & & Tartu C., Elva-Vitipalu MKA & tr_eutr & E. Oja \\
\hline LT852974 & Peltigera polydactylon & & Tartu C., Elva-Vitipalu MKA & tr_eutr & E. Oja \\
\hline LT852975 & Peltigera polydactylon & & Pärnu C., Vihtra & tr_eutr & J. Liira \\
\hline LT852976 & Peltigera polydactylon & & Ida-Viru C., Agusalu MKA & tr_eutr & E. Oja \\
\hline LT 852977 & Peltigera polydactylon & & Põlva C., Ihamaru LKA & tr_eutr & E. Oja \\
\hline LT852978 & Peltigera polydactylon & & Ida-Viru C., Puhatu LKA & tr_eutr & L. Marmor (TU39232) \\
\hline LT852979 & Peltigera polydactylon & & Ida-Viru C., Puhatu LKA & tr_eutr & A. Suija (TU39798) \\
\hline LT852980 & Peltigera polydactylon & & Lääne-Viru C., Lahemaa NP, Palmse & tr_eutr & T. Randlane \\
\hline LT852981 & Peltigera ponojensis & I & Võru C., Võru & gr_road & I. Jüriado \\
\hline LT852982 & Peltigera ponojensis & 1 & Võru C., Hargla & gr_park & I. Jüriado \\
\hline LT852983 & Peltigera ponojensis & I & Viljandi C., Kõpu & gr_road & I. Jüriado \\
\hline
\end{tabular}




\begin{tabular}{|c|c|c|c|c|c|}
\hline$\underline{\text { LT852984 }}$ & Peltigera ponojensis & I & Saare C., Karala & gr_dune & I. Jüriado \\
\hline LT852985 & Peltigera ponojensis & 1 & Saare C., Karala & gr_dune & I. Jüriado \\
\hline LT852986 & Peltigera ponojensis & 1 & Saare C., Pidula & gr_dune & I. Jüriado \\
\hline LT852987 & Peltigera ponojensis & 1 & Pärnu C., Rannametsa & gr_road & I. Jüriado \\
\hline LT852988 & Peltigera ponojensis & 1 & Pärnu C., Rannametsa & gr_road & I. Jüriado \\
\hline LT852989 & Peltigera ponojensis & II & Võru C., Hargla & gr_park & I. Jüriado \\
\hline LT852990 & Peltigera ponojensis & II & Saare C., Järve & gr_dune & I. Jüriado \\
\hline LT852991 & Peltigera ponojensis & II & Pärnu C., Rannametsa & gr_oligotr & I. Jüriado \\
\hline LT852992 & Peltigera ponojensis & II & Pärnu C., Rannametsa & gr_road & I. Jüriado \\
\hline LT852993 & Peltigera ponojensis & II & Saare C., Pidula & gr_dune & M.-L. Kämärä \\
\hline LT852994 & Peltigera ponojensis & II & Ida-Viru C., Raadna & gr_road & I. Jüriado \\
\hline LT852995 & Peltigera ponojensis & II & Ida-Viru C., Raadna & gr_road & I. Jüriado \\
\hline LT852996 & Peltigera praetextata & & Viljandi C., Kõpu & ro_park & I. Jüriado \\
\hline LT852997 & Peltigera praetextata & & Tartu C., Järvselja & tr_eutr & I. Jüriado \\
\hline LT852998 & Peltigera praetextata & & Tartu C., Järvselja & tr_eutr & I. Jüriado \\
\hline LT852999 & Peltigera praetextata & & Lääne-Viru C., Suurekivi & tr_eutr & I. Jüriado \\
\hline LT853000 & Peltigera praetextata & & Lääne-Viru C., Suurekivi & tr_eutr & I. Jüriado \\
\hline LT853001 & Peltigera praetextata & & Tartu C., Elva-Vitipalu MKA & tr_eutr & E. Oja \\
\hline LT853002 & Peltigera praetextata & & Ida-Viru C., Muraka LKA & tr_eutr & E. Oja \\
\hline LT853003 & Peltigera praetextata & & Harju C., Väike-Pakri & ro_eutr & A. Suija (TU42658) \\
\hline LT853004 & Peltigera rufescens & & Võru C., Hargla & gr_park & I. Jüriado \\
\hline
\end{tabular}




\begin{tabular}{|c|c|c|c|c|}
\hline LT853005 & Peltigera rufescens & Võru C., Hargla & gr_park & I. Jüriado \\
\hline LT853006 & Peltigera rufescens & Võru C., Varstu Parish, Singa & gr_oligotr & I. Jüriado \\
\hline LT853007 & Peltigera rufescens & Võru C., Varstu Parish, Singa & gr_oligotr & I. Jüriado \\
\hline LT853008 & Peltigera rufescens & Võru C., Varstu Parish, Singa & gr_oligotr & I. Jüriado \\
\hline LT853009 & Peltigera rufescens & Võru C., Varstu Parish, Singa & gr_oligotr & I. Jüriado \\
\hline LT853010 & Peltigera rufescens & Võru C., Võru & gr_road & I. Jüriado \\
\hline LT853011 & Peltigera rufescens & Lääne C., Hanila & gr_road & I. Jüriado \\
\hline LT853012 & Peltigera rufescens & Lääne C., Hanila & gr_road & I. Jüriado \\
\hline LT853013 & Peltigera rufescens & Saare C., Järve & gr_dune & I. Jüriado \\
\hline ㄴT853014 & Peltigera rufescens & Saare C., Järve & gr_dune & I. Jüriado \\
\hline LT853015 & Peltigera rufescens & Saare C., Pidula & gr_dune & I. Jüriado \\
\hline LT853016 & Peltigera rufescens & Saare C., Pidula & gr_dune & I. Jüriado \\
\hline LT853017 & Peltigera rufescens & Saare C., Pidula & gr_dune & I. Jüriado \\
\hline LT853018 & Peltigera rufescens & Saare C., Pidula & gr_dune & I. Jüriado \\
\hline LT853019 & Peltigera rufescens & Saare C., Katri & gr_alvar & I. Jüriado \\
\hline LT853020 & Peltigera rufescens & Pärnu C., Rannametsa & gr_oligotr & I. Jüriado \\
\hline LT853021 & Peltigera rufescens & Pärnu C., Rannametsa & gr_oligotr & I. Jüriado \\
\hline LT853022 & Peltigera rufescens & Pärnu C., Rannametsa & gr_oligotr & I. Jüriado \\
\hline LT853023 & Peltigera rufescens & Saare C., Pidula & gr_dune & M.-L. Kämärä \\
\hline LT853024 & Peltigera rufescens & Ida-Viru C., Kauksi & gr_dune & I. Jüriado \\
\hline LT853025 & Peltigera rufescens & Ida-Viru C., Kauksi & gr_dune & I. Jüriado \\
\hline
\end{tabular}




\begin{tabular}{|c|c|c|c|c|c|}
\hline$\underline{\text { LT853026 }}$ & Peltigera rufescens & & Ida-Viru C., Kauksi & gr_dune & I. Jüriado \\
\hline LT853027 & Peltigera rufescens & & Ida-Viru C., Raadna & gr_road & I. Jüriado \\
\hline LT853028 & Peltigera rufescens & & Ida-Viru C., Lohusuu & gr_oligotr & I. Jüriado \\
\hline LT853029 & Peltigera rufescens & & Tartu C., Rõngu & ro_park & T. Randlane \\
\hline LT853030 & Peltigera rufescens & & Harju C., Lahemaa NP, Kaberneeme & ro_road & A. Suija \\
\hline LT853031 & Peltigera leucophlebia & I & Hiiu C., Kadakalaid & gr_alvar & $\begin{array}{l}\text { I. Jüriado, A. Suija } \\
\text { (TU29593) }\end{array}$ \\
\hline LT853032 & Peltigera leucophlebia & 1 & Harju C., Suur-Pakri & gr_alvar & $\begin{array}{l}\text { E. Leppik, A. Suija } \\
\text { (TU67862) }\end{array}$ \\
\hline LT853033 & Peltigera leucophlebia & IV & Lääne-Viru C., Varangu & gr_eutr & M. Leis (TU36673) \\
\hline LT853034 & Peltigera leucophlebia & IV & Hiiu C., Vohilaid & gr_alvar & $\begin{array}{l}\text { I. Jüriado, A. Suija } \\
\text { (TU29124) }\end{array}$ \\
\hline LT853035 & Peltigera leucophlebia & IV & Saare C., Paadla & gr_alvar & E. Oja \\
\hline LT853036 & Peltigera aphthosa & & $\begin{array}{l}\text { Lääne-Viru C., Lahemaa NP, Käsmu } \\
\text { peninsula }\end{array}$ & ro_oligotr & A. Suija (TU45233) \\
\hline LT853037 & Peltigera aphthosa & & Harju C., Põhja-Kõrvemaa, Paukjärve & gr_oligotr & A. Palo \\
\hline$\underline{\text { LT853038 }}$ & Peltigera malacea & & Harju C., Põhja-Kõrvemaa, Paukjärve & gr_oligotr & A. Palo \\
\hline LT853039 & Peltigera polydactylon & & Põlva C., Ihamaru LKA & tr_eutr & E. Oja \\
\hline LT853040 & Peltigera polydactylon & & Tartu C., Padakõrve LKA & tr_eutr & E. Oja \\
\hline LT853041 & Peltigera canina & III & Ida-Viru C., Muraka LKA, Kaukavere & gr_eutr & P. Lõhmus (TU47639) \\
\hline LT853042 & Peltigera canina & II & Pärnu C., Kihnu & gr_road & P. Degtjarenko \\
\hline LT853043 & Peltigera canina & II & Järva C., Kolu & tr_eutr & E. Oja \\
\hline LT853044 & Peltigera canina & II & Tartu C., Välgi LKA & tr_eutr & E. Oja \\
\hline LT853045 & Peltigera canina & II & Tartu C., Järvselja & gr_park & T. Randlane \\
\hline
\end{tabular}




\begin{tabular}{|c|c|c|c|c|c|}
\hline LT853046 & Peltigera canina & III & Saare C., Muhu, Koguva & ro_road & I. Jüriado \\
\hline LT853047 & Peltigera canina & III & Põlva C., Valgesoo & gr_oligotr & P. Degtjarenko \\
\hline LT853048 & Peltigera canina & III & Võru C., Karisöödi & tr_eutr & A. Palo \\
\hline LT853049 & Peltigera canina & III & Saare C., Korese & alvar & E. Oja \\
\hline LT853050 & Peltigera praetextata & & Põlva C., Ihamaru LKA & tr_eutr & E. Oja \\
\hline LT853051 & Peltigera praetextata & & Tartu C., Järvselja & gr_road & I. Jüriado \\
\hline LT853052 & Peltigera praetextata & & Lääne C., Puhtu & tr_eutr & I. Jüriado \\
\hline LT853053 & Peltigera praetextata & & Lääne-Viru C., Kunda & tr_eutr & A. Palo \\
\hline LT853054 & Peltigera praetextata & & Lääne-Viru C., Padaorg & tr_eutr & A. Palo \\
\hline LT853055 & Peltigera ponojensis & II & Pärnu C., Häädemeeste & gr_road & I. Jüriado \\
\hline LT853056 & Peltigera ponojensis & 1 & Saare C., Korese & gr_alvar & E. Oja \\
\hline
\end{tabular}


Table S2. Alignment information, including both the newly generated sequences (each identical genotype included only once) and the sequences downloaded from the NCBI Genbank. Bare numbers were calculated by excluding the outgroup* sequences; the numbers including the outgroup sequences are given in the parentheses. Variable sites include gaps as a fifth state.

\begin{tabular}{|c|c|c|c|c|}
\hline Peltigera section & $\begin{array}{l}\text { Number of } \\
\text { sequences }\end{array}$ & $\begin{array}{l}\text { Alignment } \\
\text { length }\end{array}$ & $\begin{array}{l}\text { Variable } \\
\text { sites }\end{array}$ & *outgroup \\
\hline Peltidea & $17(19)$ & $571(616)$ & $63(245)$ & FJ709038 Peltigera polydactylon, FJ708953 P. kristinssonii \\
\hline Horizontales & $18(20)$ & $668(683)$ & $199(312)$ & AY257929 Peltigera didactyla, JX195320 P. praetextata \\
\hline Polydactylon & $40(42)$ & $714(728)$ & $323(382)$ & KX897211 Peltigera melanorrhiza, KX897311 P. scabrosa \\
\hline Peltigera, group canina & $50(54)$ & $679(713)$ & $282(376)$ & $\begin{array}{l}\text { AY257891 Peltigera kristinssonii , AY257893 P. frigida, } \\
\text { AY257890 P. continentalis, KJ095107 P. isidiofora }\end{array}$ \\
\hline Peltigera, group rufescens & $96(101)$ & $764(791)$ & $462(512)$ & $\begin{array}{l}\text { AY257890 Peltigera canina, AY257955 P. "neocanina", } \\
\text { AY257980 P. continentalis, AY257891 P. kristinssonii, } \\
\text { AY257893 P. frigida }\end{array}$ \\
\hline
\end{tabular}

